\title{
Inheritance and Bulked Segregant Analysis of Leaf Rust and Stem Rust Resistance in Durum Wheat Genotypes
}

\author{
Meriem Aoun, James A. Kolmer, Matthew N. Rouse, Shiaoman Chao, Worku Denbel Bulbula, \\ Elias M. Elias, and Maricelis Acevedo ${ }^{\dagger}$
}

First author: Department of Plant Pathology, North Dakota State University, Fargo 58108; second and third authors: United States Department of Agriculture-Agricultural Research Service (USDA-ARS), Cereal Disease Laboratory, and Department of Plant Pathology, University of Minnesota, St. Paul 55108; fourth author: USDA-ARS Genotyping Laboratory, Biosciences Research Laboratory, Fargo, ND, 58102; fifth author: Ethiopian Institute of Agricultural Research, P.O. Box 32, Debre Zeit, Ethiopia; sixth author: Department of Plant Sciences, North Dakota State University; and seventh author: International Programs, College of Agriculture and Life Sciences, Cornell University, Ithaca, NY. Accepted for publication 17 July 2017.

\begin{abstract}
Leaf rust, caused by Puccinia triticina, and stem rust, caused by P. graminis f. sp. tritici, are important diseases of durum wheat. This study determined the inheritance and genomic locations of leaf rust resistance $(L r)$ genes to $P$. triticina race BBBQJ and stem rust resistance $(S r)$ genes to P. graminis f. sp. tritici race TTKSK in durum accessions. Eight leaf-rustresistant genotypes were used to develop biparental populations. Accessions PI 192051 and PI 534304 were also resistant to P. graminis f. sp. tritici race TTKSK. The resulting progenies were phenotyped for leaf rust and stem rust response at seedling stage. The $L r$ and $S r$ genes were mapped

in five populations using single-nucleotide polymorphisms and bulked segregant analysis. Five leaf-rust-resistant genotypes carried single dominant $L r$ genes whereas, in the remaining accessions, there was deviation from the expected segregation ratio of a single dominant $L r$ gene. Seven genotypes carried $L r$ genes different from those previously characterized in durum. The single dominant $L r$ genes in PI 209274, PI 244061, PI387263, and PI 313096 were mapped to chromosome arms 6BS, 2BS, 6BL, and 6BS, respectively. The $S r$ gene in PI 534304 mapped to 6AL and is most likely $S r 13$, while the Sr gene in PI 192051 could be uncharacterized in durum.
\end{abstract}

Durum wheat (Triticum turgidum L. var. durum (Desf.)), an allotetraploid $(2 \mathrm{n}=4 \mathrm{x}=28)$, is economically an important cereal crop used primarily for pasta production. Durum wheat is grown mainly in the Mediterranean countries, Canada, Mexico, the United States, and Ethiopia (Goyeau et al. 2012; Habash et al. 2009; Ordoñez and Kolmer 2007b; Vavilov 1951). North Dakota is the largest durumproducing state in the United States, accounting for more than $50 \%$ of the total U.S. production, which is worth more than $\$ 300$ million per year (NASS 2016).

Wheat rust diseases have historically been a major constraint for wheat production, severely reducing yield and kernel quality. Durum wheat has been traditionally considered more resistant to leaf rust (caused by Puccinia triticina Erikss.) than common wheat (T. aestivum $\mathrm{L}$.; $2 \mathrm{n}=6 \mathrm{x}=42$ ). However, in recent years, $P$. triticina races highly virulent on resistant durum wheat cultivars are increasingly affecting durum production worldwide (Goyeau et al. 2006; Huerta-Espino et al. 2009; Singh et al. 2004). For instance, $P$. triticina race $\mathrm{BBG} / \mathrm{BN}$ and its variants, with virulence to leaf rust resistance $(L r)$ gene $L r 72$, overcame the resistance of the adapted CIMMYT durum wheat cultivars in northwestern Mexico, which resulted in severe yield losses (Huerta-Espino et al. 2011; Singh et al. 2004). Similarly, increased susceptibility of durum wheat cultivars to leaf rust occurred in other durum-producing areas, including the Mediterranean basin, the Middle East, and Chile (Goyeau et al. 2012; Martinez et al. 2005; Ordoñez and Kolmer 2007a; Singh et al. 2004). In the United States, a race with a virulence phenotype

†Corresponding author: M. Acevedo; E-mail: ma934@cornell.edu

*The $\boldsymbol{e}$-Xtra logo stands for "electronic extra" and indicates that one supplementary table is published online.

This article is in the public domain and not copyrightable. It may be freely reprinted with customary crediting of the source. The American Phytopathological Society, 2017. and simple sequence repeat (SSR) genotype similar to the previously identified BBG/BN Mexican race was collected on durum in California in 2009 (Kolmer 2013). This race was designated as BBBQJ following the $P$. triticina nomenclature system of Long and Kolmer (1989). The same race was later collected in 2013 on 'Overley' hard red winter wheat in Kansas (Kolmer 2015). This race is also virulent to $L r 39 / 41$ that is present in many hard red winter wheat cultivars grown in the Southern Great Plains. This race could become established in the winter wheat crop and then migrate northward to the durum producing region of North Dakota (Kolmer 2015).

Typically, the $P$. triticina isolates virulent on durum wheat cultivars are different in their virulence phenotypes from the common wheat-type isolates because these are avirulent to many of the $L r$ genes present in common wheat (Goyeau et al. 2006; Ordoñez and Kolmer 2007a). The P. triticina isolates collected from common wheat are generally avirulent on durum wheat (Huerta-Espino and Roelfs 1992; Ordoñez and Kolmer 2007a; Singh 1991). Currently, few $L r$ genes have been mapped in durum wheat. Characterized $L r$ genes in durum and other tetraploid wheat subspecies include $L r 3 a$ (Herrera-Foessel et al. 2005), Lr10 (Aguilar-Rincon et al. 2001), Lr14a (Herrera-Foessel et al. 2008b), Lr23 (McIntosh and Dyck 1975; Nelson et al. 1997), the complementary gene pair $L r 27+31$ (Singh and McIntosh 1984; Singh et al. 1993), Lr33 (Dyck 1994; Dyck et al. 1987), Lr46 (Herrera-Foessel et al. 2011), Lr47 (Dubcovsky et al. 1998), Lr52 (Singh et al. 2010), Lr61 (Herrera-Foessel et al. 2008a), Lr64 (Dyck 1994; McIntosh et al. 2009), Lr72 (Herrera-Foessel et al. 2014a), and LrCamayo (Herrera-Foessel et al. 2007). However, races with virulence to most of these $L r$ genes are currently present. For instance, virulence to $L r 10, L r 23$, and $L r 33$ is common in durum-type P. triticina races (Huerta-Espino and Roelfs 1992; Ordoñez and Kolmer 2007a; Singh et al. 2005). In addition, $P$. triticina race BBG/ $\mathrm{BN}$ and its variants are virulent to $\operatorname{Lr72}$ (Huerta-Espino et al. 2011; Singh et al. 2004). A P. triticina race virulent to $L r 27+L r 31$ and $L r 3 a$ was detected in Mexico in 2008 (Huerta-Espino et al. 2009). Similarly, a race of $P$. triticina that was collected in Mexico in 2010 is virulent to 
Lr61 (Herrera-Foessel et al. 2014b). The gene Lr14a is not effective against the common races currently present in France, Spain, Chile, Argentina, Morocco, and Tunisia (Gharbi et al. 2013; Goyeau et al. 2012; Ordoñez and Kolmer 2007a; Soleiman et al. 2016) (J. A. Kolmer and M. Acevedo, unpublished). Therefore, the identification of new $L r$ genes is crucial to mitigate durum wheat yield loss caused by leaf rust.

Stem rust, caused by $P$. graminis f. sp. tritici Erikss. \& Henning, is one of the most destructive diseases of common wheat and durum wheat that can result in a complete loss of the crop under high disease severity (McIntosh and Brown 1997; Singh et al. 2011). The race TTKSK (Ug99) was first detected in Uganda in 1998 (Pretorius et al. 2000). This race spread to Kenya in 2001 and to Ethiopia by 2003. It was later detected in Sudan, Yemen, Iran, South Africa, and Egypt (Jin et al. 2008; Nazari et al. 2009; Pretorius et al. 2010; RustTracker. org 2016). Currently, more than 60 stem rust resistance $(\mathrm{Sr})$ genes have been identified in wheat (McIntosh et al. 2013, 2014; Rahmatov et al. 2016) and approximately 29 are effective to races of the Ug99 race group (Niu et al. 2014; Yu et al. 2014; Yu et al. 2015). However, the resistance levels conferred by these $\mathrm{Sr}$ genes differ. For instance, only a few of these Ug99-effective $S r$ genes are effective to a broad spectrum of other P. graminis f. sp. tritici races (Singh et al. 2015; Yu et al. 2014). In addition, many of these $\mathrm{Sr}$ genes were transferred to wheat from wild relatives, thus reducing the linkage drag associated with the alien translocations carrying the genes is required before using these resistance sources in breeding lines (Singh et al. 2011, 2015).

In durum wheat, the mapped $S r$ genes and quantitative trait loci associated with stem rust resistance are limited compared with those mapped in common wheat. The resistance to race TTKSK in durum wheat, particularly in the North American cultivars, is mainly due to the presence of $\mathrm{Sr} 13$ originating from the emmer wheat (T. turgidum L. subsp. dicoccum) 'Khapli' (Jin et al. 2007; Klindworth et al. 2007). However, in recent years, $P$. graminis f. sp. tritici races different from the Ug99 lineage group (TRTTF and JRCQC) have been identified in Ethiopia with combined virulence on $\mathrm{Srl3}$ and $\mathrm{Sr} 9 e$ (Olivera et al. 2012, 2015). Therefore, widening the global genetic diversity of stem rust resistance in durum wheat germplasm is urgently required for more durable resistance.

Whereas quantitative adult plant resistance, often based on several minor alleles or genes (Gustafson and Shaner 1982), is a very important objective in breeding programs, pyramiding several qualitative resistance genes that can be identified at the seedling stage is another approach to achieve durable resistance. Seedling tests allow for screening many lines in a short period of time and small space compared with adult-plant tests in field trials (Letta et al. 2014).

The use of biparental mapping populations has been the standard approach to identify the chromosomal locations of plant disease resistance loci. Bulked segregant analysis (BSA) is a quick and relatively inexpensive method to efficiently identify molecular markers associated with a trait response. The procedure consists of comparing two pooled DNA samples of individuals from a segregating population originating from a single cross. Within each bulk, the individuals are identical for the trait or gene of interest but are segregating randomly for all other genes. The two bulks that are contrasting for a trait such as response to a disease are analyzed to find molecular markers that differentiate them. Therefore, the markers that are polymorphic between the pools will be linked genetically to the locus that is associated with the trait used to make the bulk (Michelmore et al. 1991).

The objective of the current study was to determine the inheritance of leaf rust (P. triticina race BBBQJ) and stem rust (P. graminis $\mathrm{f}$. $\mathrm{sp}$. tritici race TTKSK) resistance at the seedling stage in eight durum wheat genotypes selected from the United States Department of Agriculture (USDA) National Small Grains Collection (NSGC), Aberdeen, ID. Genomic regions of the $\mathrm{Lr}$ and $\mathrm{Sr}$ genes were mapped in five biparental populations using high-density single-nucleotide polymorphism (SNP) markers and the BSA approach.

\section{MATERIALS AND METHODS}

Biparental crosses and characterization of leaf rust resistance inheritance. Eight resistant genotypes were selected from the USDA-NSGC for their low infection types to $P$. triticina race BBBQJ to develop biparental populations (Table 1). These genotypes were plant introduction (PI) 534304, PI 313096, PI 387263 , PI 209274, PI 278379, PI 244061, PI 192051, and PI 195693. These genotypes were previously reported to carry resistance to several $P$. triticina races at the seedling stage in the greenhouse and at the adult-plant stage in the field in several locations worldwide (Aoun et al. 2016). These resistant parental lines were originally collected from Ethiopia, Portugal, Cyprus, Australia, Malta, and Yemen. All of these genotypes are landraces, except for PI 209274, which is a breeding line. The susceptible parents of the crosses were 'Rusty' or 'Divide'. Divide was released in 2005 by North Dakota State University (NDSU) and currently occupies approximately $30 \%$ of the total durum wheat acreage in North Dakota (NASS 2015). The rustsusceptible line Rusty (registration number GS-155, PI 639869) was released in 2004 by the USDA Agricultural Research Service (ARS) Northern Crops Science Laboratory, Fargo, ND and NDSU (Klindworth et al. 2006).

Crosses between resistant and susceptible parents were made at the North Dakota Agricultural Experiment Station Greenhouse Complex, Fargo, during summer 2013. In all of the biparental populations, Rusty and Divide were the female parents of the crosses and the resistant genotypes were the pollen donors. Biparental crosses were advanced using the single-seed-descent method to generation $\mathrm{F}_{6}$, except for the biparental crosses involving the resistant genotypes PI 192051, PI 244061, and PI 195693, which were advanced to generation $\mathrm{F}_{3}$. The biparental populations were screened at the seedling stage with $P$. triticina race BBBQJ during winter months (December to February) in the biosafety level-two facility at the Agricultural Experiment Station Greenhouse Complex in Fargo, ND, in generations $\mathrm{F}_{1}, \mathrm{~F}_{2}, \mathrm{~F}_{3}$, and $\mathrm{F}_{6}$.

The single-pustule isolate CA1.2 of race BBBQJ was originally isolated from a sample collected from durum wheat fields in California. Its virulence/avirulence phenotype was given based on infection types (IT) at the seedling stage on the international differential sets of 'Thatcher' wheat near-isogenic lines, with each line carrying a single $L r$ resistance gene (Long and Kolmer 1989). The virulence/ avirulence profile of race BBBQJ is $L r B, 10,14 b, 20$, and $39 / L r l, 2 a$, $2 c, 3 a, 3 k a, 3 b g, 9,11,14 a, 16,17,18,24,26,28$, and 30 .

The inheritance of the gene or genes was determined in each of the biparental crosses. For the crosses that were evaluated at $F_{1}$, five to six seeds were evaluated for response to race BBBQJ. For the crosses that were tested at the $F_{2}$ stage, 118 to 342 plants were evaluated for disease response. At the $\mathrm{F}_{3}$ generation, approximately 18 to 30 seedlings from each $\mathrm{F}_{3}$ family (101 to 255 families/population) were screened. The $\mathrm{F}_{6}$ recombinant inbred lines (RIL) from each

TABLE 1. Origin, type, and reaction to leaf rust and stem rust of the parental genotypes used in the crosses

\begin{tabular}{|c|c|c|c|c|}
\hline $\begin{array}{l}\text { Parents of } \\
\text { the crosses }\end{array}$ & Type & Origin & $\begin{array}{c}\text { IT to } \\
\text { BBBQJa }^{2}\end{array}$ & $\begin{array}{c}\text { IT to } \\
\text { TTKSK }^{\mathrm{b}}\end{array}$ \\
\hline PI 534304 & Landrace & Ethiopia & $; 1-$ & 2 \\
\hline PI 192051 & Landrace & Portugal & 0 & $2-$ \\
\hline PI 313096 & Landrace & Cyprus & $; 1-$ & . \\
\hline PI 387263 & Landrace & Ethiopia & $; 1$ & . \\
\hline PI 209274 & Breeding line & Australia & $; 1$ & . \\
\hline PI 278379 & Landrace & Malta & $; 1+$ & . \\
\hline PI 244061 & Landrace & Yemen & $; 1$ & . \\
\hline PI 195693 & Landrace & Ethiopia & ; & . \\
\hline Rusty $^{\mathrm{c}}$ & Line & North Dakota & $3+$ & $3+$ \\
\hline Divide $^{c}$ & Cultivar & North Dakota & 3 & . \\
\hline
\end{tabular}

${ }^{a}$ Infection types (IT) of the parental genotypes to Puccinia triticina race BBBQJ.

b IT of the parental genotypes to $P$. graminis $\mathrm{f}$. $\mathrm{sp}$. tritici race TTKSK.

c Susceptible parents of the crosses. 
tested population were evaluated in a randomized complete block design, with three replications with five to eight seeds from each RIL per replicate. For all tests, the seedlings were grown in the greenhouse as described by Kertho et al. (2015). The resistant and susceptible parents of each cross, the susceptible durum wheat genotype 'RL6089', and the susceptible common wheat Thatcher were included in each tray as checks. Two replicates of differentials of Thatcher nearisogenic lines were planted alongside each experiment to confirm the purity of the race BBBQJ. Urediniospore increase, inoculation, incubation, and greenhouse conditions were completed as previously described by Aoun et al. (2016).

Leaf rust IT were assessed on the second-leaf stage 12 days after inoculation using a 0-to-4 scale (Long and Kolmer 1989; McIntosh et al. 1995), where IT $0=$ no disease symptom, ; = hypersensitive flecks, $1=$ small uredinia surrounded by necrosis, $2=$ small- to medium-size uredinia surrounded by chlorosis, $3=$ medium-size uredinia with no chlorosis or necrosis, and $4=$ large uredinia with no chlorosis or necrosis. The mesothetic reaction (X reaction) is a mixture of fleck and higher infection types evenly distributed on the leaf surface. The seedlings showing IT of 0 to $2+$ and $X$ were considered resistant, whereas the plants showings IT of 3 and 4 were considered susceptible (Long and Kolmer 1989; McIntosh et al. 1995).

Based on the IT, the $\mathrm{F}_{2}$ plants were classified as resistant $(\mathrm{R})$ or susceptible $(\mathrm{S})$. The $\mathrm{F}_{3}$ families and the RIL were classified as homozygous resistant (HR), segregating (Seg), and homozygous susceptible (HS). The number of genes that were involved in the inheritance of leaf rust resistance were estimated based on segregation ratios and $\chi^{2}$ goodness-of-fit tests. The segregating $\mathrm{F}_{6}$-derived RIL were excluded when computing the $P$ values of the $\chi^{2}$ test because only approximately $3 \%$ of the RIL were expected to be segregating.

Characterization of stem rust resistance inheritance in two biparental crosses. Two of the biparental populations that were described above, Rusty $\times$ PI 534304 and Rusty $\times$ PI 192051, were also screened with $P$. graminis f. sp. tritici race TTKSK (isolate $04 \mathrm{KEN} 156 / 04)$ at the seedling stage at generation $\mathrm{F}_{3}$. The genotype PI 192051 was previously reported to be resistant to race TTKSK by Olivera et al. (2012), whereas PI 534304 was identified to be resistant to race TTKSK in the current study. Rusty was the susceptible parent to $P$. graminis f. sp. tritici race TTKSK. The avirulence/virulence profile of race TTKSK is $S r 24,36, T m p / S r 5,6,7 b, 8 a, 9 a, 9 b, 9 d, 9 e, 9 g$, $10,11,17,21,30,31,38, M c N$.

The disease screenings were conducted in a biosafety level-three facility at the University of Minnesota, St. Paul. Twenty plants of each $\mathrm{F}_{3}$ family were inoculated approximately 10 days after planting with $P$. graminis f. sp. tritici race TTKSK. Urediniospores, stored at $-80^{\circ} \mathrm{C}$, were heat shocked at $45^{\circ} \mathrm{C}$ for $15 \mathrm{~min}$, then rehydrated at room temperature under a relative humidity of $80 \%$ created with a $\mathrm{KOH}$ solution (Rowell 1984). The plants were inoculated as previously described by Rouse et al. (2012). Thereafter, the plants were transferred to a greenhouse maintained at $18 \pm 2{ }^{\circ} \mathrm{C}$ with a $16-\mathrm{h}$ photoperiod until evaluation of disease. Stem rust IT were assessed 14 days after inoculation using the 0-to-4 Stakman scale (Stakman et al. 1962). Seedlings showing IT of 0 to $2+$ were considered resistant and those with IT of 3 to 4 were considered susceptible.

Based on the IT, the $\mathrm{F}_{3}$ families were classified as HR, Seg, or HS. The segregation ratios were analyzed using $\chi^{2}$ goodness-of-fit tests. This allowed for the estimation of the number of genes involved in the inheritance of stem rust resistance. The number of families evaluated for Rusty $\times$ PI 534304 and Rusty $\times$ PI 192051 were 131 and 118 , respectively.

BSA. Based on the inheritance study, four biparental populations that carry single $L r$ genes and one population that carries a single $\mathrm{Sr}$ gene were chosen for BSA. Leaf tissues from each population were collected from the $\mathrm{F}_{2}$ plants. This was done before the plants were advanced to the next generation.

The genomic regions associated with response to $P$. triticina race BBBQJ were identified in the biparental populations Divide $\times$ PI 313096, Rusty $\times$ PI 387263, Rusty $\times$ PI 209274, and Divide $\times$ PI
244061. For the populations derived from Rusty $\times$ PI 209274 and Divide $\times$ PI 244061, BSA was performed using DNA extracted from $10 \mathrm{HR}$ and $10 \mathrm{HS} \mathrm{F}_{2}$ plants. The homozygous $\mathrm{F}_{2}$ plants were identified by phenotyping $\mathrm{F}_{2: 3}$ seedlings. For the remaining two populations, BSA was done using DNA extracted from 20 to $22 \mathrm{HR}$ and 20 to $22 \mathrm{HS} \mathrm{F}_{6}$ RIL.

The biparental cross Rusty $\times$ PI 534304 was used to locate the genomic region associated with response to $P$. graminis f. sp. tritici race TTKSK. The DNA of $16 \mathrm{HR}$ and $16 \mathrm{HS}$ RIL were used in the BSA. Because this population was screened with race TTKSK only at the $\mathrm{F}_{3}$ generation, The $\mathrm{HR}$ and $\mathrm{HS} \mathrm{F}_{6}$ RIL were identified for BSA based on the phenotype of the corresponding $\mathrm{F}_{2: 3}$ families.

The DNA of HR and HS plants was extracted using a cetyltrimethylammonium bromide extraction method described by Riede and Anderson (1996) and modified by Liu et al. (2006). Additional modifications of lyophilizing and grinding the leaf tissue were as described by Rouse et al. (2012). The DNA was then diluted to $50 \mathrm{ng} / \mu \mathrm{l}$ and pooled in equal volumes to obtain resistant and susceptible bulks, as described by Michelmore et al. (1991). The HR and HS bulks and parents in each of the crosses were genotyped using Illumina's custom wheat iSelect 9K SNP array (Cavanagh et al. 2013) at the USDA-ARS Small Grain Genotyping Laboratory in Fargo, ND. The data generated were scored using Illumina Genome Studio software.

Response of the resistant genotypes to $P$. triticina races virulent to known $\boldsymbol{L r}$ genes mapped in durum wheat cultivars. In order to verify whether the resistant genotypes that were used to develop the biparental crosses carry previously characterized $\mathrm{Lr}$ genes in durum wheat cultivars, $P$. triticina races with virulence to $L r 3 a, L r 14 a, L r 27+31, L r 61$, and $L r 72$ were used to phenotype the parents of the crosses.

Eleven durum cultivars were also included in this test, including 'Alred' as a susceptible check, the susceptible parents of the crosses (Rusty and Divide), 'Llareta INIA' carrying Lr14a (Herrera-Foessel et al. 2008a), 'Camayo' carrying LrCamayo (Herrera-Foessel et al. 2007), 'Jupare C2001' carrying Lr27+31 (Singh and McIntosh 1984; Singh et al. 1993), 'Guayacan INIA' carrying Lr61 (Herrera-Foessel et al. 2008b), 'Capelli', 'Mindum', 'Russello', and 'Mexicali75'. The $P$. triticina races used were BBBSJ, CBBQS, and BBB/BN_Lr61 vir. Race BBB/BN_Lr61 vir is avirulent to $L r 72$, which is widely present in CIMMYT's durum germplasm (Herrera-Foessel et al. 2014a) and virulent to $L r 10, L r 23$, and $L r 61$. The race BBBSJ was collected from durum in Spain in 2014 and is virulent to $L r B, L r 10, L r 14 a, L r 14 b$, $L r 20, L r 23$, and $L r 72$. The race CBBQS (also called CBG/BP based on the CIMMYT differential sets) was collected from durum fields in Mexico in 2008 and is virulent to $L r B, L r 3 a, L r 3 b g, L r 10, L r 14 b$, $L r 23$, Lr27+31, and Lr72 (Huerta-Espino et al. 2009) (J. HuertaEspino, personal communication).

Mapping of $\boldsymbol{L r}$ genes in PI 209274, PI 387263, and PI 244061. Based on the results of the BSA, we selected three biparental populations (Rusty $\times$ PI 209274, Rusty $\times$ PI 387263, and Divide $\times$ PI 244061) to complete linkage mapping of the $L r$ trait and molecular markers. These populations were chosen because they were thought to carry previously uncharacterized $L r$ genes in durum cultivars. F $_{6}$ RIL for populations Rusty $\times$ PI 209274 and Rusty $\times$ PI 387263 and $F_{2}$ plants of the cross Divide $\times$ PI 244061 were used for linkage mapping.

In total, 130 RIL of the cross Rusty $\times$ PI 209274 and 97 RIL derived from Rusty $\times$ PI 387263 that were phenotyped using $P$. triticina race $\mathrm{BBBQJ}$ were genotyped with their respective markers identified during the BSA and additional markers from the 90K teteraploid consensus map (Maccaferri et al. 2015). In all, 11 SSR and 34 kompetitive allele-specific polymerase chain reaction (KASP) markers were used to genotype the susceptible parent (Rusty) and the resistant parent (PI 209274).

For the population Rusty $\times$ PI 387263, 23 KASP markers were used to genotype the susceptible parent (Rusty) and the resistant parent (PI 387263). Only the markers showing clear polymorphism between the parents were used to genotype the RIL. 
For the population derived from Divide $\times$ PI 244061, $93 \mathrm{~F}_{2}$ plants were used for mapping. The $\mathrm{HR}$, Seg, and $\mathrm{HS} \mathrm{F}_{2}$ plants were identified based on the phenotype of the corresponding $F_{2: 3}$ families. Thirty-four KASP markers identified during BSA, with additional markers from the $90 \mathrm{~K}$ tetraploid consensus map, were used to differentiate the susceptible parent (Divide) and the resistant parent (PI 244061). Thereafter, the polymorphic markers were used to screen the $93 \mathrm{~F}_{2}$ individuals derived from this cross. For the SSR markers that were used to genotype the parents and the RIL of the cross Rusty $\times$ PI 209274, the polymerase chain reactions (PCR) were accomplished in $25-\mu \mathrm{l}$ volumes. Each reaction contained $1 \mu \mathrm{l}$ of $10 \mu \mathrm{M}$ forward primer, $1 \mu \mathrm{l}$ of $10 \mu \mathrm{M}$ reverse primer, $2.5 \mu \mathrm{l}$ of $2.5 \mathrm{mM}$ dNTP, $5 \mu \mathrm{l}$ of $5 \times$ Green Go Taq Flexi buffer, $2.5 \mu \mathrm{l}$ of $25 \mathrm{mM}$ $\mathrm{MgCl}_{2}, 0.15 \mu \mathrm{l}$ of GoTaq Flexi DNA (Promega Corp.) at $5 \mathrm{U} / \mu \mathrm{l}$, $10.85 \mu \mathrm{l}$ of $\mathrm{H}_{2} \mathrm{O}$, and $2 \mu \mathrm{l}$ of DNA at $30 \mathrm{ng} / \mu \mathrm{l}$. The PCR were performed in thermal cyclers programed to denature the DNA at $94^{\circ} \mathrm{C}$ for $5 \mathrm{~min}$, followed by 35 cycles of $30 \mathrm{~s}$ of a $94^{\circ} \mathrm{C}$ denaturation step, $30 \mathrm{~s}$ of an annealing step (depending on the annealing temperatures of the respective SSR markers), and $45 \mathrm{~s}$ of a $72^{\circ} \mathrm{C}$ extension step. The program was then finished with a final 7-min extension step at $72^{\circ} \mathrm{C}$ and $4^{\circ} \mathrm{C}$ permanent hold. The PCR products were separated on $3 \%$ agarose gels and DNA was visualized under UV light after staining with gel red nucleic acid gel stain (Biotium).

For the KASP markers, the primer sequences were obtained from the polymaker website (http://polymarker.tgac.ac.uk/). For each KASP marker, three primers were used in PCR. Two of them are allelespecific forward primers which result in biallelic discrimination and one common reverse primer (Ramirez-Gonzalez et al. 2014, 2015). Oligos, carrying standard FAM or HEX compatible tails (FAM tail: 5'GAAGGTGACCAAGTTCATGCT3' or HEX tail: 5'GAAGGTCG GAGTCAACGGATT3') were added to the forward primer sequences with the target SNP at the $3^{\prime}$ end (Ramirez-Gonzalez et al. 2014). The PCR were in $10-\mu l$ volumes and prepared as described by the manufacturer (LGC). Each reaction contained $0.25 \mu \mathrm{l}$ of $10 \mu \mathrm{M}$ each forward primer, $0.5 \mu \mathrm{l}$ of $10 \mu \mathrm{M}$ reverse primer, $5 \mu \mathrm{l}$ of KASP $2 \times$ master $\operatorname{mix}(\mathrm{LGC}), 1 \mu \mathrm{l}$ of $\mathrm{H}_{2} \mathrm{O}$, and $3 \mu \mathrm{l}$ of DNA at $30 \mathrm{ng} / \mu \mathrm{l}$. PCR were placed in Multiplate 96-well unskirted PCR plates (MLP-9601; Bio-Rad) and sealed with an optical plate seal. The PCR were performed in a BioRad CFX-96 real-time system thermal cycler programed as follows: hot-start activation at $94^{\circ} \mathrm{C}$ for $15 \mathrm{~min}$ followed by 10 touchdown cycles of denaturation at $94^{\circ} \mathrm{C}$ for $20 \mathrm{~s}$ and annealing or elongation (61 to $55^{\circ} \mathrm{C}$ ) for $60 \mathrm{~s}$, with a drop of $0.6^{\circ} \mathrm{C}$ per cycle. This was followed by 26 cycles of a denaturation step at $94^{\circ} \mathrm{C}$ for $20 \mathrm{~s}$ and an annealing or elongation step at $55^{\circ} \mathrm{C}$ for $60 \mathrm{~s}$. The PCR plate was read at $37^{\circ} \mathrm{C}$ and fluorescent end-point genotyping was carried out. Data analysis was performed with the genotype cluster analysis software Bio-Rad CFX Manager 3.1 using the allelic discrimination option. If genotype clusters were not clearly defined after the initial KASP thermal cycle, the plate was thermally cycled for an additional three cycles of a denaturation step at $94^{\circ} \mathrm{C}$ for $20 \mathrm{~s}$ and an annealing or elongation step at $57^{\circ} \mathrm{C}$ for $60 \mathrm{~s}$ and the PCR plate was read again at $37^{\circ} \mathrm{C}$. In some cases, the latter cycling and reading was repeated until distinct genotyping clusters were obtained.

For linkage mapping, the phenotypic responses were converted into binary data based on classification as resistant or susceptible IT. Then, the phenotypic and genotypic data were combined to generate linkage maps using MapDisto.1.7.7.0.1.1 (Lorieux 2012), with minimum logarithm of odds $($ LODmin $)=7.0$ and maximum recombination frequency of 0.3 . The Kosambi mapping function was used to calculate genetic distance between markers (Kosambi 1943).

\section{RESULTS}

The inheritance of leaf rust resistance. The number of genes conferring resistance against $P$. triticina race BBBQJ in the eight durum wheat genotypes was determined by evaluating the IT at seedling stage of $F_{1}$ plants and the segregation ratios of $F_{2}, F_{3}$, and $F_{6}$ progenies (Table 2). In six of the crosses (Rusty $\times$ PI 192051, Divide $\times$ PI 244061, Rusty $\times$ PI 387263, Rusty × PI 209274, Rusty $\times$ PI 534304 , and Divide $\times$ PI 313096), the $F_{1}$ plants showed resistant IT to $P$. triticina race $\mathrm{BBBQJ}$, suggesting that the resistance was dominant. The $F_{1}$ plants of the cross Divide $\times$ PI 278379 were susceptible to BBBQJ, indicating that the resistance was recessive (Table 2).

Evaluation of $170 \mathrm{~F}_{3}$ families derived from the cross Rusty $\times$ PI 192051 showed a segregation ratio of $1: 2: 1 \mathrm{HR} / \mathrm{Seg} / \mathrm{HS}(P=0.33)$, suggesting that the $P$. triticina race BBBQJ resistance in PI 192051 is conferred by a single dominant gene. Similarly, evaluation of 255 $\mathrm{F}_{3}$ families and $98 \mathrm{~F}_{6} \mathrm{RIL}$ of the cross Divide $\times$ PI 313096 segregated as $1: 2: 1 \mathrm{HR} / \mathrm{Seg} / \mathrm{HS}(P=0.06)$ and $1: 1 \mathrm{HR} / \mathrm{HS}(P=0.05)$, respectively which also fit the expected Mendelian ratios for a single gene. Therefore, the $L r$ gene in PI 313096 is conferred by a single dominant gene (Table 2).

The segregation ratios of $311 \mathrm{~F}_{2}$ plants generated from the cross Divide $\times$ PI 244061 fit $3: 1 \mathrm{R} / \mathrm{S}(P=0.77)$. Further screening of $117 \mathrm{~F}_{3}$ families of the same cross showed a segregation of $1: 2: 1 \mathrm{HR} / \mathrm{Seg} / \mathrm{HS}$ $(P=0.06)$ which suggests that a single dominant resistance gene confers resistance to $P$. triticina race, BBBQJ in PI 244061 (Table 2).

In the cross of Rusty $\times$ PI 387263 , the $106 \mathrm{~F}_{3}$ families and $140 \mathrm{RIL}$ evaluated segregated as $1: 2: 1 \mathrm{HR} / \mathrm{Seg} / \mathrm{HS}(P=0.16)$ and $1: 1 \mathrm{HR} / \mathrm{HS}$ $(P=0.10)$, respectively. This indicated that a single dominant

TABLE 2. Characterization of leaf rust resistance (Puccinia triticina race BBBQJ) inheritance at the seedling stage in eight resistant durum genotypes based on infection types of $F_{1}$ plants and segregation ratios at $F_{2}, F_{3}$, and $F_{6}{ }^{a}$

\begin{tabular}{|c|c|c|c|c|c|c|c|c|c|c|}
\hline \multirow[b]{3}{*}{ Populations } & \multirow[b]{3}{*}{$\mathrm{F}_{1}$} & \multicolumn{3}{|c|}{$\mathrm{F}_{2}$ segregation ratios } & \multicolumn{3}{|c|}{$\mathrm{F}_{3}$ segregation ratios } & \multicolumn{3}{|c|}{$\mathrm{F}_{6}$ segregation ratios } \\
\hline & & \multicolumn{2}{|c|}{$\mathrm{R} / \mathrm{S}^{\mathrm{b}}$} & \multirow[b]{2}{*}{$P$ for $\chi^{2}$} & \multicolumn{2}{|c|}{$\mathrm{HR} / \mathrm{Seg} / \mathrm{HS}^{\mathrm{c}}$} & \multirow[b]{2}{*}{$P$ for $\chi^{2}$} & \multirow{2}{*}{$\frac{\overline{\mathrm{HR} / \mathrm{Seg} / \mathrm{HS}^{\mathrm{d}}}}{\underset{\text { Segregation }}{(n)}}$} & \multirow{2}{*}{$\frac{\mathrm{HR} / \mathrm{HS}}{\begin{array}{c}\text { Expected } \\
\text { ratio }\end{array}}$} & \multirow[b]{2}{*}{$P$ for $\chi^{2}$} \\
\hline & & $\begin{array}{c}\text { Segregation } \\
(n)\end{array}$ & $\begin{array}{l}\text { Expected } \\
\text { ratio }\end{array}$ & & $\begin{array}{l}\text { Segregation } \\
\quad(n)\end{array}$ & $\begin{array}{l}\text { Expected } \\
\text { ratio }\end{array}$ & & & & \\
\hline Rusty $\times$ PI 534304 & $1+$ & - & - & - & $17: 79: 33$ & $1: 2: 1 / 1: 8: 7$ & $0.005 * / 1.7 \mathrm{E}-05^{*}$ & $114: 2: 61$ & $1: 1 / 3: 1$ & $<1 \mathrm{E}-05 * / 0.03 *$ \\
\hline Rusty × PI 192051 & $; 1$ & - & - & - & $37: 89: 44$ & $1: 2: 1$ & 0.33 & - & - & - \\
\hline Divide $\times$ PI 313096 & $1+$ & - & - & - & $62: 144: 49$ & $1: 2: 1$ & 0.06 & $57: 3: 38$ & $1: 1$ & 0.05 \\
\hline Rusty × PI387263 & $1+$ & - & - & - & $18: 58: 30$ & $1: 2: 1$ & 0.16 & $76: 7: 57$ & $1: 1$ & 0.10 \\
\hline Divide $\times$ PI 278379 & 3 & $31: 172$ & $3: 13$ & 0.20 & - & - & - & - & - & - \\
\hline Divide $\times$ PI 244061 & $1+$ & $231: 80$ & $3: 1$ & 0.77 & $19: 69: 29$ & $1: 2: 1$ & 0.06 & - & - & - \\
\hline Rusty × PI 195693 & - & $36: 82$ & $1: 3$ & 0.38 & - & - & - & - & - & - \\
\hline Divide $\times$ PI 195693 & - & $88: 125$ & $7: 9$ & 0.48 & $18: 52: 31$ & $1: 8: 7$ & 0.18 & - & - & - \\
\hline
\end{tabular}

a Symbols: - indicates population was not evaluated at this generation and $*$ indicates $P$ value where the observed segregation ratio is significantly different from the expected segregation ratio at a $95 \%$ level of confidence.

${ }^{b}$ Number of resistant $(\mathrm{R})$ and susceptible $(\mathrm{S}) \mathrm{F}_{2}$ progenies

${ }^{c}$ Number of homozygous resistant (HR), segregating (Seg), and homozygous susceptible (HS) $\mathrm{F}_{3}$ families.

${ }^{\mathrm{d}}$ Number of homozygous resistant (HR), segregating (Seg), and homozygous susceptible (HS) recombinant inbred lines at $\mathrm{F}_{6}$ generation.

e Observed segregation ratios could fit into two possible expected segregation ratios (1:3 R/S or 3:13 R/S). 
resistance gene controls the resistance to $P$. triticina race BBBQJ in PI 387263 (Table 2).

The $F_{2}$ population (342 plants) of the cross Rusty $\times$ PI 209274 segregated as $3: 1 \mathrm{R} / \mathrm{S}(P=0.66)$ whereas the segregation ratio of $154 \mathrm{~F}_{3}$ families was $1: 2: 1 \mathrm{HR} / \mathrm{Seg} / \mathrm{HS}(P=0.78)$ and the $\mathrm{F}_{6} \mathrm{RIL}$ segregated as 1:1 HR/HS $(P=0.86)$. This suggests that a single dominant gene conferred the observed resistance in PI 209274 (Table 2).

All five $F_{1}$ plants derived from the cross Rusty $\times$ PI 534304 showed resistant IT, indicating that the resistance to $P$. triticina race BBBQJ is dominant. The subsequent screening of $129 \mathrm{~F}_{3}$ and $177 \mathrm{~F}_{6} \mathrm{RIL}$ resulted in segregation of 17:79:33 H/Seg/HS and 144:2:61 HR/Seg/ HS, respectively, which did not fit Mendelian inheritance for one or two genes, based on $P$ values of the $\chi^{2}$ test $(<0.05)$ at a $95 \%$ level of confidence (Table 2).

The segregation pattern of cross Rusty $\times$ PI 278379 showed that $\mathrm{F}_{2}$ segregation ratios could fit two possible models. One of the models was $1: 3 \mathrm{R} / \mathrm{S}(P=0.32)$, which suggests the presence of a single recessive gene controlling resistance to $P$. triticina race BBBQJ. The observed segregation at $\mathrm{F}_{2}$ also fit a $3: 13 \mathrm{R} / \mathrm{S}$ ratio $(P=0.22)$, which indicates the involvement of two genes: one dominant gene suppressing the expression of another dominant resistance gene. The same segregation ratio (3:13 R/S; $P=0.20)$ was obtained by crossing the same resistant parent PI 278379 with the susceptible parent Divide. Further evaluation of the population Rusty $\times$ PI 278379 showed fit to two ratios: 1:8:7 HR/Seg/HS $(P=0.43)$ and 1:3 HR/HS $(P=0.95)$ for $\mathrm{F}_{3}$ families and $\mathrm{F}_{6} \mathrm{RIL}$, respectively. These results suggest that two genes are most likely involved in this population (Table 2).

Two populations were developed for the resistant genotype PI 195693. Evaluation of each population suggested different modes of inheritance. The segregation ratio of $118 \mathrm{~F}_{2}$ plants of the cross Rusty $\times$ PI 195693 fit $1: 3 \mathrm{R} / \mathrm{S}(P=0.38)$, indicating that the resistance was conferred by a single recessive gene. However, the $\mathrm{F}_{2}$ plants (213 individuals) of the cross Divide $\times$ PI 195693 segregated as 7:9 R/S $(P=0.48)$, indicating the presence of two recessive genes. Further screening of the $\mathrm{F}_{3}$ lines of Divide $\times$ PI 195693 were distributed in accordance with a 1:8:7 HR/Seg/HS ratio, indicating the presence of two genes (Table 2).

Stem rust resistance inheritance. The inheritance of stem rust resistance to $P$. graminis $\mathrm{f}$. sp. tritici race TTKSK in the two populations Rusty $\times$ PI 534304 and Rusty $\times$ PI 192051 was determined based on the evaluation of $F_{3}$ progenies.

TABLE 3. Characterization of stem rust resistance (Puccinia graminis f. sp. tritici race TTKSK) inheritance at seedling stage in two resistant durum lines based on segregation ratios of $\mathrm{F}_{3}$ progenies ${ }^{\mathrm{a}}$

\begin{tabular}{lcc}
\hline Characterization & Rusty $\times$ PI 534304 & Rusty $\times$ PI 192051 \\
\hline Homozygote resistant & 27 & 31 \\
Segregating & 69 & 70 \\
Homozygote susceptible & 35 & 17 \\
Expected segregation ratio & $1: 2: 1 \mathrm{HR} / \mathrm{Seg} / \mathrm{HS}$ & $1: 2: 1 \mathrm{HR} / \mathrm{Seg} / \mathrm{HS}$ \\
$P$ value of $\chi^{2}$ & 0.51 & $0.02 *$ \\
\hline
\end{tabular}

${ }^{\mathrm{a}} \mathrm{HR}=$ homozygous resistant, Seg = segregating, and HS = homozygous susceptible. An asterisk (*) indicates $P$ value where the observed segregation ratio is significantly different from the expected segregation ratio at a $95 \%$ level of confidence.
The $131 \mathrm{~F}_{3}$ families of the biparental cross Rusty $\times$ PI 534304 fit 1:2:1 HR/Seg/HS $(P=0.51)$, which suggested that PI 534304 carries a single $\mathrm{Sr}$ gene controlling the resistance to TTKSK. The segregation observed in the cross Rusty $\times$ PI 192051 was 31:70:17 HR/ Seg/HS, which did not fit segregation for a single gene based on the $P$ value of the $\chi^{2}$ test $(P=0.02)$ (Table 3$)$.

BSA. Genomic regions associated with $\mathrm{Lr}$ and $\mathrm{Sr}$ genes were identified via BSA in five biparental populations in which the resistance appeared to be conferred by single dominant resistance genes. Four of these crosses were used to map the chromosomal regions associated with $L r$ resistance to $P$. triticina race BBBQJ, whereas one cross was used to identify the region associated with the $S r$ gene conferring resistance to $P$. graminis f. sp. tritici race TTKSK (Table 4).

Divide $\times$ PI 244061 population. Thirty-three SNP located on chromosome $2 \mathrm{~B}$ were associated with leaf rust response in the cross involving Divide $\times$ PI 244061. The positions of the SNP markers were based on the hexaploid consensus map (Cavanagh et al. 2013). Based on the BLASTn of the SNP sequences against the Chinese Spring chromosome survey sequences (https://urgi.versailles.inra. fr/blast/?dbgroup=wheat_all\&program=blastn), six markers were found on chromosome arm 2BL, while the rest of the markers were on 2BS (Table 4; Supplementary Table S1).

Rusty $\times$ PI 209274 and Divide $\times$ PI 313096 populations. The leaf rust resistance in the cross Rusty $\times$ PI 209274 was associated with 10 SNP on chromosome arm 6BS (Table 4).

Six SNP on chromosome arm 6BS were associated with leaf rust response in the population Divide $\times$ PI 313096. Even though the $\mathrm{Lr}$ genes in PI 209274 and PI 313096 were both located on 6BS, the BSA did not reveal any common SNP linked with response to $P$. triticina race BBBQJ between the two populations. However, the majority of the trait-associated SNP in both populations mapped to overlapping regions between 0.6 and 14.5 centimorgans (cM), based on the hexaploid consensus map of Cavanagh et al. (2013) (Table 4).

Rusty $\times$ PI 387263 population. Five SNP associated with leaf rust response were detected on chromosome arm $6 \mathrm{BL}$ in the cross Rusty $\times$ PI 387263 .

Rusty $\times$ PI 534304 population. Thirty-two SNP on chromosome arm 6AL were associated with stem rust response to race $P$. graminis f. sp. tritici race TTKSK in the cross Rusty $\times$ PI 534304 (Table 4).

Response of the parental genotypes to $P$. triticina races virulent to known $\boldsymbol{L r}$ genes in durum. The parents resistant to $P$. triticina race BBBQJ that were used to develop the biparental populations alongside other durum cultivars were screened using P. triticina races BBBSJ, CBBQS, and BBB/BN_Lr61vir. The IT indicated that race BBBSJ, which carries virulence to $\operatorname{LrB}, \operatorname{LrlO}$, $L r 14 a, L r 14 b, L r 23, L r 20$, and $L r 72$, was avirulent to all the resistant parents of the crosses and on Camayo and Juapare C2001 durum wheat. Race CBBQS, virulent to $L r B, L r 3 a, L r 3 b g, L r 10, L r 14 b$, $L r 23, L r 27+31$, and $L r 72$, was avirulent to the eight resistant parental genotypes used in the crosses and to Camayo and Llareta INIA. Race BBB/BN_Lr61 vir, which carries virulence on $\operatorname{Lr10}$, $L r 23$, and $L r 61$, was avirulent to all the eight genotypes and cultivars, except PI 313096, Alred, and Guayacan INIA. This suggests that the resistance in the eight genotypes used to develop the

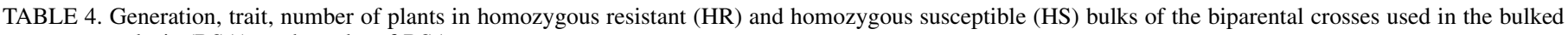
segregant analysis (BSA), and results of BSA

\begin{tabular}{|c|c|c|c|c|c|c|c|c|}
\hline Populations & Generation & Trait & Pathogen race & HS bulk $(n)^{\mathrm{a}}$ & HR bulk $(n)^{\mathrm{b}}$ & Chromosome & $\operatorname{SNP}(n)^{\mathrm{c}}$ & Possible gene \\
\hline Divide $\times$ PI 313096 & $\mathrm{~F}_{6}$ & Leaf rust & BBBQJ & 20 & 20 & $6 \mathrm{BS}$ & 6 & Lr61 \\
\hline Rusty × PI 387263 & $\mathrm{~F}_{6}$ & Leaf rust & BBBQJ & 22 & 22 & $6 \mathrm{BL}$ & 5 & Possibly novel \\
\hline Rusty $\times$ PI 209274 & $\mathrm{~F}_{2}$ & Leaf rust & BBBQJ & 10 & 10 & $6 \mathrm{BS}$ & 10 & Lr53 or possibly novel \\
\hline Divide $\times$ PI 244061 & $\mathrm{~F}_{2}$ & Leaf rust & BBBQJ & 10 & 10 & $2 \mathrm{~B}$ & 33 & Lr13 or possibly novel \\
\hline Rusty × PI 534304 & $\mathrm{~F}_{6}$ & Stem rust & TTKSK & 16 & 16 & $6 \mathrm{AL}$ & 32 & Srl3 \\
\hline
\end{tabular}

a Number of HS $F_{2}$ plants or recombinant inbred lines (RIL) included in the HS bulk.

b Number of HR $F_{2}$ plants or RIL included in the HR bulk.

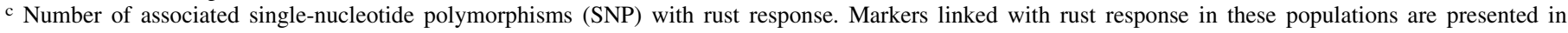
Supplementary Table S1. 
biparental populations is conferred by different or additional genes than the previously characterized $L r$ genes in durum cultivars, including $L r 3 a, L r 14 a, L r 27+31, L r 61$, and $L r 72$, except PI 313096, which most likely carries Lr61 (Table 5).

Mapping of the $\boldsymbol{L r}$ gene in PI 209274. The population Rusty $\times$ PI 209274 was selected for linkage mapping using $130 \mathrm{~F}_{6}$ RIL. The identified SNP on 6BS that were associated with leaf rust response in this population using BSA spanned a genomic region of $21.9 \mathrm{cM}$, based on the consensus map of Cavanagh et al. (2013) (Table 4).

The SNP markers identified in the biparental cross Rusty $\times$ PI 209274 using BSA were used to develop KASP markers, as described by RamirezGonzalez et al. (2014). Three KASP markers (KASP_6BS_IWA7070, KASP_6BS_IWA3298, and KASP_6BS_IWA4290) gave clear polymorphism between the resistant parent (PI 209274) and the susceptible parent (Rusty). Therefore, these KASP markers were used initially to genotype the RIL of this biparental population. The mapping of the $L r$ gene associated with leaf rust response to $P$. triticina race BBBQJ in PI 209274 showed that the gene was initially flanked by KASP_6BS_IWA3298 and KASP_6BS_IWA7070. Therefore, additional SNP and SSR markers located between these two markers, based on the tetraploid consensus map (Maccaferri et al. 2015), were used to genotype the parents of the cross. Five KASP assay SNP and one SSR (dupw217) markers that were polymorphic between the parents were then used to genotype the $\mathrm{F}_{6}$ RIL. The mapping identified two flanking markers (KASP_6BS_IWA3298 and KASP_6BS_IWB39456) that delineated the $L r$ gene resistant to race BBBQJ, here designated as LrPI209274 (Fig. 1).

The distance between the flanking markers was $4.7 \mathrm{cM}$. The marker KASP_6BS_IWA3298 was the most closely linked to LrPI209274 at a distance of $1.0 \mathrm{cM}$ whereas KASP_6BS_IWB39456 was located at $3.7 \mathrm{cM}$ distal to LrPI209274. The rest of markers were located further away from the gene, with most of them distal to the gene (Fig. 1). All linked markers with LrPI209274 (Fig. 1) in this durum population conformed to the expected ratio of $1: 1$ at a 95\% level of confidence ( $P$ values of $\chi^{2}$ tests ranged from 0.13 to 0.84 for the KASP markers and $P=0.05$ for the SSR marker dupw217). The primer sequences of the KASP markers used for mapping of LrPI209274 as well as the alleles associated with resistance are presented in Table 6.

Mapping of the $\boldsymbol{L r}$ gene in PI 387263. For the population Rusty $\times$ PI 387263 , the BSA revealed five SNP on 6BL that are associated with leaf rust response. Based on the $9 \mathrm{~K}$ wheat consensus

TABLE 5. Infection types of the parental genotypes of the crosses and durum wheat cultivars to Puccinia triticina races BBBSJ, CBBQS, and BBB/BN_Lr6lvir at the seedling stage

\begin{tabular}{lccc}
\hline Entries & BBBSJ $^{\mathrm{a}}$ & CBBQS $^{\mathrm{b}}$ & BBB/BN_Lr61vir $^{\mathrm{c}}$ \\
\hline PI 534304 & $0 ;$ & $;$ & $; 1-$ \\
PI 192051 & $;$ & $; 1$ & $;$ \\
PI 313096 & $0 ;$ & $0 ;$ & $3+$ \\
PI 387263 & $;$ & $; 1$ & $; 1-$ \\
PI 209274 & $; 1+$ & $\ldots$ & X \\
PI 278379 & $; 2+\mathrm{C}$ & $2+\mathrm{C}$ & $; 1+$ \\
PI 244061 & $;$ & $;$ & $\ldots$ \\
PI 195693 & $;$ & $; 1$ & $; 1$ \\
Rusty & 3 & 3 & $\ldots$ \\
Divide & $2+3$ & 3 & $\ldots$ \\
Alred & 3 & 4 & $3+$ \\
Llareta INIA & 3 & $; 13-$ & X \\
Camayo & $; 1-$ & $; 1$ & $; 1$ \\
Jupare C 2001 & $; 1$ & 3 & $\ldots$ \\
Capelli & $2+3$ & $3+$ & $\ldots$ \\
Mindum & 3 & 3 & $\ldots$ \\
Russello & 3 & 3 & $\ldots$ \\
Mexicali 75 & 3 & 3 & 3 \\
Guayacan INIA & $\ldots$ & $\ldots$ &
\end{tabular}

${ }^{a}$ P. triticina race virulent to $\operatorname{LrB}, \operatorname{Lr} 10, \operatorname{Lr} 14 a, \operatorname{Lr} 14 b, \operatorname{Lr} 20, \operatorname{Lr} 23$, and $\operatorname{Lr} 72$.

b $P$. triticina race virulent to $L r B, L r 3 a, L r 3 b g, L r 10, L r 14 b, L r 23, L r 27+31$, and $\operatorname{Lr} 72$.

c P. triticina race virulent to $\operatorname{Lr} 10, \operatorname{Lr} 23$, and $\operatorname{Lr} 61$. map (Cavanagh et al. 2013), these markers span a genomic region of $30.0 \mathrm{cM}$. Because the number of SNP identified during the BSA was limited, additional SNP from the $90 \mathrm{~K}$ tetraploid consensus map were used for further genotyping to saturate the region. The SNP from the BSA and others falling within the regions were used to develop KASP markers for further testing. All the polymorphic markers between the two parents were subsequently applied to screen the RIL. Initial mapping showed that the $L r$ gene associated with leaf rust response to $P$. triticina race BBBQJ in PI 387263 is located distal to KASP_6BL_IWB72635. Additional KASP markers found distal to marker $K A S P \_6 B L \_I W B 72635$ were used to more accurately map the $L r$ gene. The final mapping showed that $K A S P \_6 B L \_I W B 44753$ was the closest and mapped at a distance of $2.8 \mathrm{cM}$ from the gene. The $L r$ gene in PI 387263 mapped at the distal end of chromosome 6BL and is hereby designated as LrPI387263 (Fig. 2).

KASP markers used for mapping LrPI387263 deviated from the expected ratio of $1: 1$ at a $95 \%$ level of confidence based on the $P$ values of $\chi^{2}$ tests, except $K A S P \_6 B L \_44753$. The primer sequences of the KASP markers used for mapping of $\operatorname{LrPI387263}$ as well as the alleles associated with resistance are presented in Table 6.

Mapping of the $\boldsymbol{L r}$ gene in PI 244061. For the population Divide $\times$ PI 244061, the BSA revealed 33 SNP on chromosome 2B that are associated with leaf rust response. Based on the $9 \mathrm{~K}$ wheat consensus map (Cavanagh et al. 2013), these markers occupy a genomic region spanning $98.6 \mathrm{cM}$. The polymorphic KASP markers, derived from the identified SNP during the BSA, were used to genotype the $\mathrm{F}_{2}$ progenies. Initial mapping indicated that the $L r$ gene in PI 244061 is located distal to KASP_2BS_IWA5392. Subsequently, more KASP markers found distal to KASP_2BS_IWA5392 based on the $90 \mathrm{~K}$ tetraploid consensus map were developed. Application of the polymorphic markers on $\mathrm{F}_{2}$ progenies mapped the $\mathrm{Lr}$ gene distal to KASP_2BS_IWB6117 at a distance of $11.5 \mathrm{cM}$. This gene was hereby designated as LrPI244061 (Fig. 3).

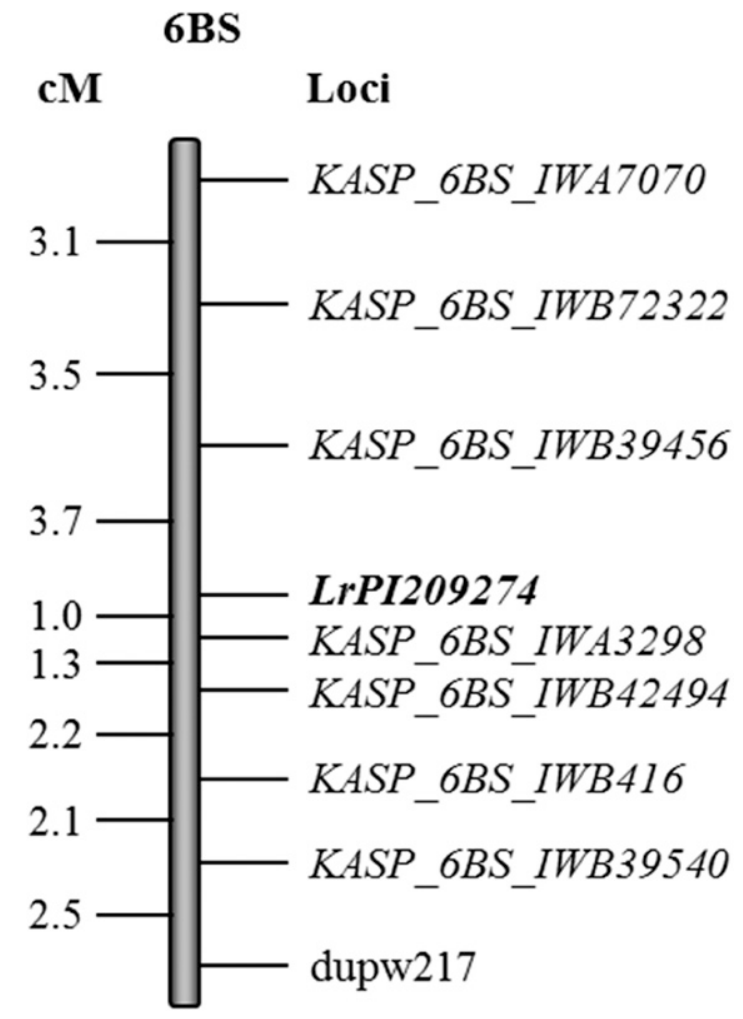

Fig. 1. Distance in centimorgans (cM) between simple sequence repeat (SSR) and kompetitive allele-specific polymerase chain reaction (KASP) assay singlenucleotide polymorphism markers linked to the leaf rust (Puccinia triticina race BBBQJ) resistance gene (LrPI209274) on chromosome arm 6BS using phenotypic and genotypic data of the recombinant inbred lines of the cross Rusty $\times$ PI 209274 at $F_{6}$ generation. 
KASP markers used for mapping LrPI244061 conformed to the expected ratio of $1: 1$ at a $95 \%$ level of confidence based on $\chi^{2}$ tests, except for $K A S P \_2 B S \_I W B 67561, K A S P \_2 B S \_I W A 5392$, $K A S P \_2 B S \_I W A 1763$, and $K A S P \_2 B S \_I W A 837$. The primer sequences of the KASP markers used for mapping of LrPI244061 as well as the alleles associated with resistance are shown in Table 6.

\section{DISCUSSION}

P. triticina race BBBQJ, highly virulent on tetraploid wheat, was recently found in the southern Great Plains region of the United States (Kolmer 2015). Therefore, the spread of this race to North Dakota, the major durum-producing region of the United States, is possible. Because most of the North Dakota durum cultivars are susceptible to this race and few effective $L r$ genes are available to the durum wheat breeding programs globally, we aimed to identify new $L r$ genes. In the present study, resistance to $P$. triticina race BBBQJ was conferred by single dominant genes in five of the durum populations. BSA showed that the genomic locations of the Lrgenes in in PI 209274, PI 244061, PI387263, and PI 313096 mapped to chromosome arms 6BS, 2BS, 6BL, and 6BS, respectively. This was a fast and relatively inexpensive method to identify that the resistance in these four genotypes was conferred by at least three different genes. This method assessed the genetic diversity of resistance in these genotypes and identified possible new $L r$ genes that can be used to broaden the genetic diversity of leaf rust resistance in durum wheat. Apart from being resistant to BBBQJ, the eight genotypes used to develop these populations showed a broad spectrum of resistance to several $P$. triticina races collected worldwide at the seedling stage in the greenhouse and at the adult-plant stage in field trials (Aoun et al. 2016). In addition, based on our results from the current study, these genotypes are resistant to $P$. triticina races virulent to commonly used $L r$ genes in durum breeding programs, including $L r 3 a, L r 14 a, L r 27+31$, Lr61, and L72, suggesting that new or underutilized $L r$ genes may be present in theses genotypes. The genotypes utilized were collected from different countries and seven of eight were landraces. Wheat landraces are known to carry new resistance genes to several diseases, including rust, because the use of landraces in the modern breeding programs is not frequent (Bonman et al. 2007; Bux et al. 2012; Gurung et al. 2014; Newton et al. 2010; Reif et al. 2005).
Our study showed that the $L r$ gene in PI 244061 was mapped to chromosome 2BS. Several previously mapped $L r$ genes on 2 BS have been reported, including Lr23 (McIntosh and Dyck 1975; Nelson et al. 1997; Watson and Luig 1961). However, PI 244061 was resistant to races BBBSJ and CBBQS, which are virulent to $L r 23$. Virulence to Lr23 is common in P. triticina races isolated from durum wheat (Huerta-Espino and Roelfs 1992; Ordoñez and Kolmer 2007a; Singh et al. 2005). In addition, the map position of $\operatorname{LrPI} 244061$ is distal to Lr23, which is tightly linked to KASP_69462 (Chhetri et al. 2017). Other genes on 2BS include Lr13 (Singh et al. 1992) and Lrl6 (Zhang and Knott 1990) that have been postulated in durum. Lrl6 is tightly linked to SSR (wmc764 and wmc661) and SNP markers that are on the distal end of chromosome 2BS (Kassa et al. 2017; McCartney et al. 2005) However, the map position of LrPI244061 is proximal to Lr16, based on the tetraploid consensus map (Maccaferri et al. 2015). Therefore, the $L r$ gene in PI 244061 is unlikely to be $L r 16$. Because the Lrl3 Thatcher line is resistant to $P$. triticina race BBBQJ at the seedling stage (Kolmer 2015), the $L r$ gene in PI 244061 is possibly Lrl3. Another seedling resistance gene on 2BS, designated as $L r 73$, was mapped in the common wheat line 'Morocco' (Park et al. 2014). However, Morocco is highly susceptible to race BBBQJ, suggesting that $L r 73$ is

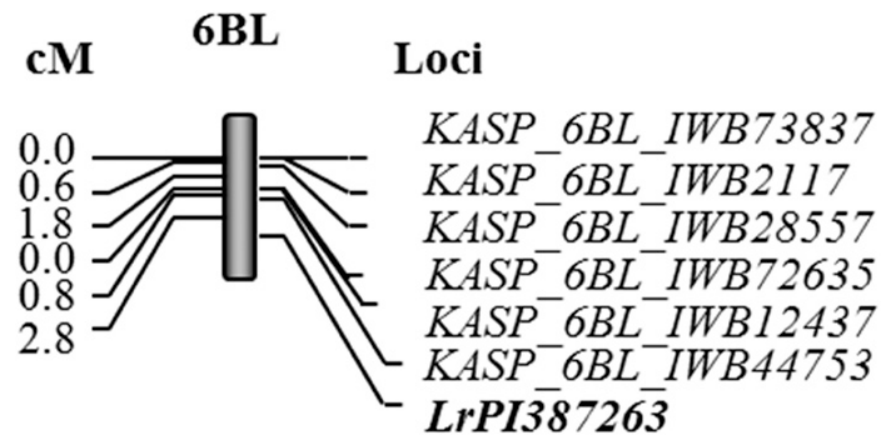

Fig. 2. Distance in centimorgans (cM) between kompetitive allele-specific polymerase chain reaction (KASP) assay single-nucleotide polymorphism markers linked to the leaf rust (Puccinia triticina race BBBQJ) resistance gene ( $L r P I 387263)$ on chromosome arm 6BL using phenotypic and genotypic data of the recombinant inbred lines of the cross Rusty $\times$ PI 387263 at $\mathrm{F}_{6}$ generation.

TABLE 6. Primers of kompetitive allele-specific polymerase chain reaction (KASP) assay markers derived from the $90 \mathrm{~K}$ iSelect assay for mapping leaf rust resistance genes effective to Puccinia triticina race BBBQJ in the populations Rusty $\times$ PI209274, Rusty $\times$ PI387263, and Divide $\times$ PI244061

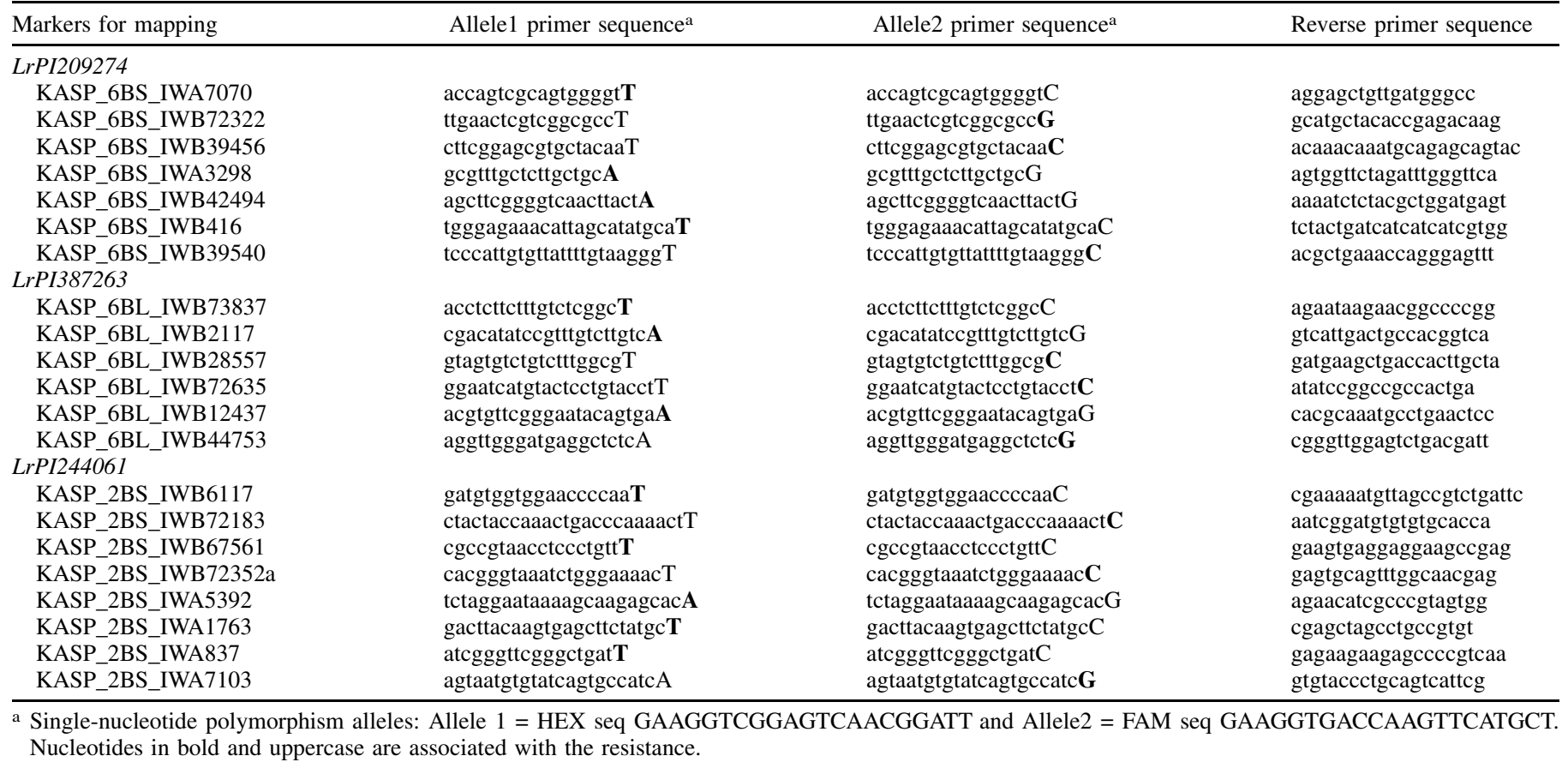


not the gene of interest in PI 244061. Therefore, the $L r$ gene in PI 244061 is possibly $L r 13$ or a new $L r$ gene.

The $L r$ genes in PI 209274 and PI 313096 were both located on chromosome arm 6BS. Lr61 is the only known gene on 6BS in durum cultivars identified to date and was previously mapped in CIMMYT Guayacan INIA wheat (Herrera-Foessel et al. 2008a). The genotype PI 313096 was susceptible to $P$. triticina race BBB/BN_Lr61 vir, suggesting that the resistance in PI 313096 is most likely Lr61. The latter is effective against the $P$. triticina race used in this study (BBBQJ). PI 209274 was resistant to BBB/BN_Lr61vir, indicating that the single dominant $L r$ gene in PI 209274 differs from $L r 61$.

Other $L r$ genes mapped on 6BS in wheat include $L r 36$ originating from Aegilops speltoides (Dvořák and Knott 1990), Lr53 from T. turgidum subsp. dicoccoides (Dadkhodaie et al. 2011; Marais et al. 2005), and Lr59 originating from A. peregrina (Marais et al. 2008; Pirseyedi et al. 2015). The genes $L r 36$ and $L r 59$ were transferred to hexaploid wheat from wild relatives, which makes them unlikely to be the $L r$ gene in PI 209274. Therefore, the $L r$ gene in PI209274 is likely $L r 53$ or a previously uncharacterized gene.

The $L r$ genes in the population Rusty X PI 387263 were located on chromosome arm 6BL. Herrera-Foessel et al. (2007) identified two linked genes in repulsion on chromosome 6BL that were effective against $P$. triticina race BBG/BN collected in Mexico: Lr3a and LrCamayo. The gene Lr3a that cosegregated with Xmwg798 (Sacco et al. 1998) was confirmed to be present in 'Storlom' durum wheat (Herrera-Foessel et al. 2007). In the present study, PI 387263 is resistant to the $P$. triticina race CBBQS which is virulent to $L r 3 a$, indicating that the resistance gene in PI 387263 is different from Lr3a. Further screening of Camayo and PI 387263 with P. triticina isolate Eth-63-1 (race EEEEE, avirulent on Thatcher) collected from durum wheat in Ethiopia showed virulence on PI 387263 but not on Camayo (M. Aoun, unpublished). This suggests that the resistance in PI 387263 is possibly conferred by a different gene from LrCamayo. Therefore, the $L r$ gene in PI387263 is likely new.

The genotype PI 195693 showed resistance to BBBSJ, CBBQS, and BBB/BN_Lr61vir. Therefore, the resistance in PI 195693 is conferred by a different gene or a gene in addition to $\operatorname{LrB}, \operatorname{Lr} 3 a$, Lr3bg, Lr10, Lr14a, Lr14b, Lr20, Lr23, Lr27+31, Lr61, and Lr72. The $\mathrm{F}_{2}$ segregation ratio of 1:3 R/S in the cross Rusty $\times$ PI 195693 (one recessive gene) and 7:9 R/S in the cross Divide $\times$ PI 195693 (two recessive genes) could be due to the difference in the genetic background of the susceptible parents Divide and Rusty. Even though the segregation ratio of 1:8:7 HR/Seg/HS at generation $\mathrm{F}_{3}$ in Divide $\times \mathrm{PI}$ 195693 could confirm the presence of two recessive genes, the same ratio could also suggest the involvement of two complementary dominant genes. Similar segregation patterns at the seedling stage (susceptible $\mathrm{F}_{1}, 7: 9 \mathrm{R} / \mathrm{S}$ at $\mathrm{F}_{2}$, and 1:8:7 $\mathrm{HR} / \mathrm{Seg} / \mathrm{HS}$ at $\mathrm{F}_{3}$ ) were observed previously in the cross 'Atil C200' $\times$ 'Hualita' to the Mexican P. triticina race BBG/BN (Herrera-Foessel et al. 2005). However, Herrera-Foessel et al. (2005) reported that the resistance in the cross Atil C200 $\times$ Hualita was due to the presence of two dominant complementary genes rather than two recessive genes because the $\mathrm{F}_{1}$ plants were resistant in the field. Only one single case of complementary genes with dominant interaction conditioning leaf rust resistance has been reported in durum wheat. Jupare C2001 and 'Banamichi C2004' durum wheat carry the complementary genes Lr27+31 on chromosome arms $3 \mathrm{BS}$ and 4BL, respectively (HerreraFoessel et al. 2005, 2014b) that were originally characterized in common wheat (Singh and McIntosh 1984; Singh et al. 1993).

The $\mathrm{F}_{1}$ plants of the cross Divide $\times$ PI 278379 were susceptible to $P$. triticina race $\mathrm{BBBQJ}$, indicating the presence of recessive resistance (dominant susceptibility) to leaf rust. The segregation of 3:13 R/S in generation $\mathrm{F}_{2}$ of Rusty $\times$ PI 278379 and Divide $\times$ PI 278379 populations and the distribution of $1: 8: 7 \mathrm{HR} / \mathrm{Seg} / \mathrm{HS}$ in the $\mathrm{F}_{3}$ families and $1: 3 \mathrm{HR} / \mathrm{HS}$ in the $\mathrm{F}_{6}$ RIL of Rusty $\times \mathrm{PI} 278379$ could mean the involvement of one dominant resistance gene with one suppressor gene. A possible scenario for this ratio might be due to the presence of a dominant resistance gene in PI 278379 that is suppressed by a suppressor gene from the susceptible parent (Rusty or Divide). Cases of suppressor genes of rust resistance have been reported in wheat-rust pathosystems. For instance, a suppressor gene of $L r 23$ designated as SuLr23 on chromosome arm 2DS that was derived from A. tauschii was identified in synthetic hexaploid wheat (Nelson et al. 1997). In addition, suppressors of $L r$ genes have been identified in the A and B genomes in durum wheat (Assefa and Fehrman 2000). Knott (2000) also characterized suppressors of $\mathrm{Sr}$ genes in the A and B genomes in 'Medea' durum wheat.

The resistance to $P$. triticina race BBBQJ in the population Rusty $\times$ PI 534304 is dominant, whereas the segregation ratios at generations $\mathrm{F}_{3}$ and $\mathrm{F}_{6}$ did not fit expected segregation ratios for one or two genes. The same population was used to map an $\mathrm{Sr}$ gene effective to $P$. graminis f. sp. tritici race TTKSK. The resistance to race TTKSK in PI 534304 is conferred by a single resistance gene that is located on chromosome arm 6AL. Chromosome arm 6AL is also known to carry Srl3 (Jin et al. 2007; Klindworth et al. 2007), which is commonly found in durum wheat cultivars. However, a diagnostic marker of Srl3 is currently not available. The IT of PI 534304 and the segregating population to $P$. graminis f. sp. tritici race TTKSK were similar to that of $S r 13$. Therefore, the $S r$ resistance in PI 534304 is most probably $\mathrm{Sr} 13$. Unfortunately, this $\mathrm{Sr}$ gene is not effective against the select $P$. graminis f. sp. tritici races in Ethiopia such as JRCQC (Olivera et al. 2012).

PI 192051 carries a single dominant $L r$ gene effective to P. triticina race BBBQJ. Interestingly, PI 192051 showed a broad spectrum of resistance to several $P$. triticina races tested in a previous study by Aoun et al. (2016). In addition, PI 192051 is resistant to $P$. graminis f. sp. tritici race TTKSK. The stem rust resistance in the cross Rusty $\times$ PI 192051 did not follow the segregation ratio of a single gene. PI 192051 was not only resistant to $P$. graminis f. sp. tritici race TTKSK but also to $P$. graminis $\mathrm{f}$. sp. tritici race JRCQC, with virulence to $\mathrm{Sr} 13$ and $\mathrm{Sr} 9 e$, which are common in durum

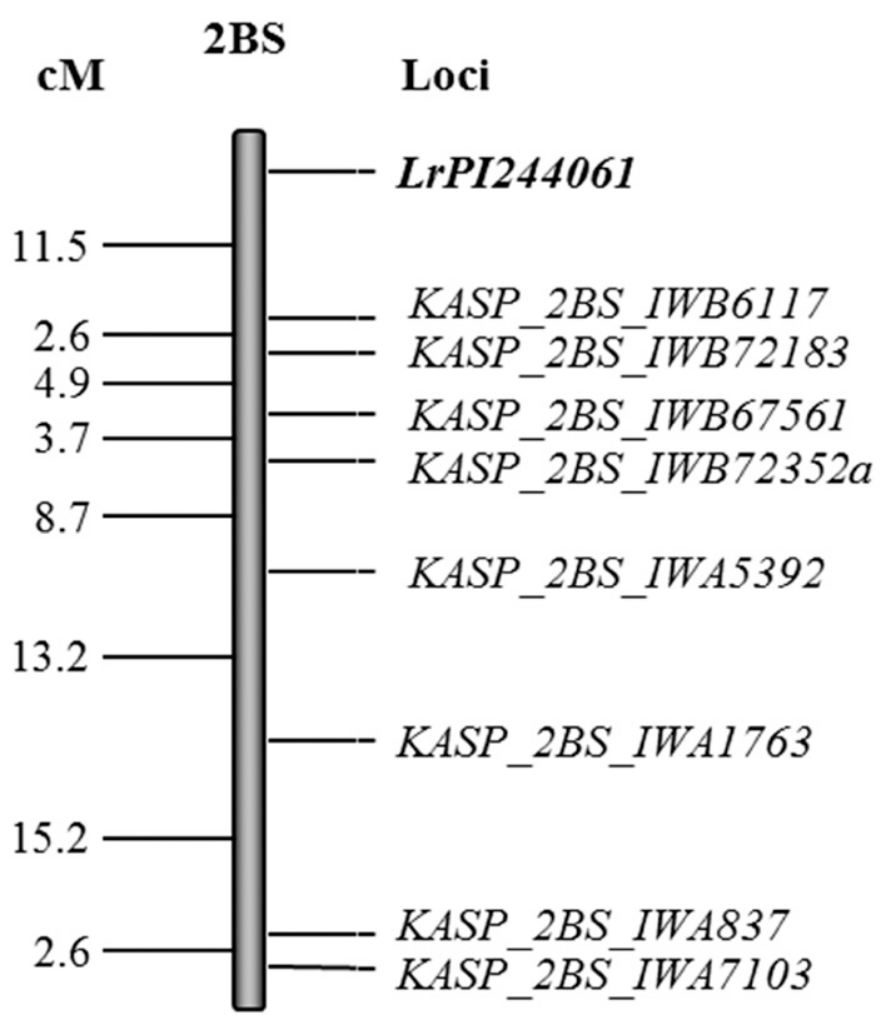

Fig. 3. Distance in centimorgans (cM) between kompetitive allele-specific polymerase chain reaction (KASP) assay single-nucleotide polymorphism markers linked to the leaf rust (Puccinia triticina race BBBQJ) resistance gene ( Lr244061) on chromosome arm 2BS using phenotypic and genotypic data of $\mathrm{F}_{2}$ plants of the cross Divide $\times$ PI 244061. 
wheat cultivars (Olivera et al. 2012). The genotype PI 192051 was also highly resistant in field trials in Debre Zeit, Ethiopia in 2009 (Olivera et al. 2012), 2014, and 2016 (unpublished data). Thus, PI 192051 is an effective source of resistance not only to race $\mathrm{Ug} 99$ but also to other $P$. graminis $\mathrm{f}$. sp. tritici races recently observed in Ethiopia which are phylogenetically different from the Ug99 race group. Mapping of $\mathrm{Lr}$ and $\mathrm{Sr}$ genes in PI 192051 is ongoing because this genotype seems to carry previously uncharacterized genes in durum cultivars with a broad spectrum of resistance.

Conclusion. The objective of the current study was to identify new sources of resistance to leaf rust and stem rust that can be useful to broaden the narrow rust resistance spectrum in durum wheat. Eight durum genotypes from the USDA-NSGC that are mainly landraces and come from different geographical locations were used in the current study. The inheritance study revealed that five of the crosses (Rusty $\times$ PI 192051, Divide $\times$ PI 244061, Rusty $\times$ PI387263, Rusty $\times$ PI 209274, and Divide $\times$ PI 313096) carried single dominant $L r$ genes effective to $P$. triticina race BBBQJ. In the remaining crosses (Rusty $\times$ PI 534304, Rusty $\times$ PI 278379, Rusty $\times$ PI 195693, and Divide $\times$ PI 195693), the inheritance of $L r$ genes was more complex, involving recessive resistance, two genes, or deviation from simple Mendelian inheritance. The leaf rust resistance in seven genotypes used to develop the biparental populations was conferred, at least in part, by genes different from previously mapped genes in durum cultivars The eight genotypes resistant to $\mathrm{BBBQJ}$ have resistance to additional $P$. triticina races tested at both the seedling stage in the greenhouse and at the adult stage in field trials. Therefore, more research is needed to verify whether the resistance to different races in each of these genotypes is conferred by the same or different genes. The BSA showed that the $L r$ genes in PI 209274, PI 244061, PI387263, and PI 313096 were mapped to chromosome arms 6BS, 2BS, 6BL, and 6BS, respectively. Further mapping of the likely new or underutilized $\mathrm{Lr}$ genes using KASP markers narrowed down the genomic regions of the $L r$ genes in PI 244061, PI 387263, and PI 209274. LrPI387263 mapped to $2.8 \mathrm{cM}$ distal to KASP_6BL_IWB44753, LrPI244061 mapped to $11.5 \mathrm{cM}$ distal to KASP_2BS_IWB6117, and LrPI209274 was flanked by $K A S P \_6 B S \_I W B 39456$ and $K A S P \_6 B S \_I W A 3298$ to a 4.7-cM region. Two of the eight genotypes were also resistant to P. graminis f. sp. tritici race TTKSK. The resistance in PI 534304 was conferred by a single dominant gene on 6AL, which is most likely Sr13. PI 192051 possessed a wide spectrum of resistance to $P$. graminis f. sp. tritici races. which could be conferred by an uncharacterized resistance gene in durum germplasm.

\section{ACKNOWLEDGMENTS}

We thank J. Huerta-Espino for kindly providing some of the $P$. triticina races used in this study; and A. Swank, J. Glasgow, and the wheat personnel at the EIAR-Debre Zeit Research Center for their technical support. This work was supported by the North Dakota Wheat Commission, the North Dakota State Board of Research and Education, and the Bill \& Melinda Gates Foundation (OPP1133199).

\section{LITERATURE CITED}

Aguilar-Rincon, V. H., Singh, R. P., Castillo-Gonzalez, F., and Huerta-Espino, J. 2001. Genes of leaf rust resistance in a synthetic hexaploid wheat. Rev. Fitotec. Mex. 24:161-169.

Aoun, M., Breiland, M., Kathryn Turner, M., Loladze, A., Chao, S., Xu, S. S., Ammar, K., Anderson, J. A., Kolmer, J. A., and Acevedo, M. 2016. Genomewide association mapping of leaf rust response in a durum wheat worldwide germplasm collection. Plant Genome 9.

Assefa, S., and Fehrman, H. 2000. Resistance to wheat leaf rust in Aegilops tauschii Coss. and inheritance of resistance in hexaploid wheat. Genet. Resour. Crop Evol. 47:135-140.

Bonman, J. M., Bockelman, H. E., Jin, Y., Hijmans, R. J., and Gironella, A. I. N. 2007. Geographic distribution of stem rust resistance in wheat landraces. Crop Sci. 47:1955-1963.
Bux, H., Ashraf, M., and Chen, X. 2012. Expression of high-temperature adult-plant (HTAP) resistance against stripe rust (Puccinia striiformis $\mathrm{f}$. sp. tritici) in Pakistan wheat landraces. Can. J. Plant Pathol. 34:68-74.

Cavanagh, C. R., Chao, S., Wang, S., Huang, B. E., Stephen, S., Kiani, S., Forrest, K., Saintenac, C., Brown-Guedira, G. L., Akhunova, A., See, D., Bai, G., Pumphrey, M., Tomar, L., Wong, D., Kong, S., Reynolds, M., da Silva, M. L., Bockelman, H., Talbert, L., Anderson, J. A., Dreisigacker, S., Baenziger, S., Carter, A., Korzun, V., Morrell, P. L., Dubcovsky, J., Morell, M. K., Sorrells, M. E., Hayden, M. J., and Akhunov, E. 2013. Genome-wide comparative diversity uncovers multiple targets of selection for improvement in hexaploid wheat landraces and cultivars. Proc. Natl. Acad. Sci. USA 110: 8057-8062.

Chhetri, M., Bariana, H., Wong, D., Sohail, Y., Hayden, M., and Bansal, U. 2017. Development of robust molecular markers for marker-assisted selection of leaf rust resistance gene $L r 23$ in common and durum wheat breeding programs. Mol. Breed. 37:21.

Dadkhodaie, N. A., Karaoglou, H., Wellings, C. R., and Park, R. F. 2011. Mapping genes Lr53 and Yr35 on the short arm of chromosome 6B of common wheat with microsatellite markers and studies of their association with Lr36. Theor. Appl. Genet. 122:479-487.

Dubcovsky, J., Lukaszewski, A. J., Echaide, M., Antonelli, E. F., and Porter, D. R. 1998. Molecular characterization of two Triticum speltoides interstitial translocations carrying leaf rust and greenbug resistance genes. Crop Sci. 38: 1655-1660.

Dvořák, J., and Knott, D. R. 1990. Location of a Triticum speltoides chromosome segment conferring resistance to leaf rust in Triticum aestivum. Genome 33:892-897.

Dyck, P. L. 1994. The transfer of leaf rust resistance from Triticum turgidum ssp. dicoccoides to hexaploid wheat. Can. J. Plant Sci. 74:671-673.

Dyck, P. L., Kerber, E. R., and Lukow, O. M. 1987. Chromosome location and linkage of a new gene (Lr33) for reaction to Puccinia recondita in common wheat. Genome 29:463-466.

Gharbi, M. S., Ammar, K., Berrias, S., Karboul, K., and Manel, A. 2013. Mitigating the threat of leaf rust to durum yield stability in new Septoria tritici blotch resistant germplasm in Tunisia. Presented at: Borlaug Global Rust Initiative Tech. Workshop, New Delhi, India.

Goyeau, H., Berder, J., Czerepak, C., Gautier, A., Lanen, C., and Lannou, C. 2012. Low diversity and fast evolution in the population of Puccinia triticina causing durum wheat leaf rust in France from 1999 to 2009, as revealed by an adapted differential set. Plant Pathol. 61:761-772.

Goyeau, H., Park, R., Schaeffer, B., and Lannou, C. 2006. Distribution of pathotypes with regard to host cultivars in French wheat leaf rust populations. Phytopathology 96:264-273.

Gurung, S., Mamidi, S., Bonman, J. M., Xiong, M., Brown-Guedira, G., and Adhikari, T. B. 2014. Genome-wide association study reveals novel quantitative trait loci associated with plant immunity against major leaf spot diseases of spring wheat. PLoS One 9:e108179.

Gustafson, G. D., and Shaner, G. 1982. The influence of plant age on the expression of slow-mildewing resistance in wheat. Phytopathology 72:746-749.

Habash, D. Z., Kehel, Z., and Nachit, M. 2009. Genomic approaches for designing durum wheat ready for climate change with a focus on drought. Aust. J. Bot. 60:2805-2815.

Herrera-Foessel, S. A., Huerta-Espino, J., Calvo-Salazar, V., Lan, C. X., and Singh, R. P. 2014a. Lr72 confers resistance to leaf rust in durum wheat cultivar Atil C2000. Plant Dis. 98:631-635.

Herrera-Foessel, S. A., Singh, R. P., Huerta-Espino, J., Calvo-Salazar, V., Lan, C., and Basnet, B. R. 2014b. Achieving sustainable leaf rust control in durum wheat: What have we learnt and how to move forward. In: Proc. Borlaug Global Rust Initiative Tech. Obregón, Mexico. www.globalrust. org/sites/default/files/2014\%20BGRI\%20Herrera-Foessel.pdf

Herrera-Foessel, S. A., Singh, R. P., Huerta-Espino, J., Salazar, V. C., and Lagudah, E. S. 2011. First report of slow rusting gene Lr46 in durum wheat. In: Technical workshop in Borlaug global rust initiative, St. Paul, MN.

Herrera-Foessel, S. A., Singh, R. P., Huerta-Espino, J., William, H. M., Djurle, A., and Yuen, J. 2008a. Molecular mapping of a leaf rust resistance gene on the short arm of chromosome 6B of durum wheat. Plant Dis. 92:1650-1654.

Herrera-Foessel, S. A., Singh, R. P., Huerta-Espino, J., William, H. M., Garcia, V., Djurle, A., and Yuen, J. 2008b. Identification and molecular characterization of leaf rust resistance gene Lr14a in durum wheat. Plant Dis. 92: 469-473.

Herrera-Foessel, S. A., Singh, R. P., Huerta-Espino, J., William, M., Rosewarne, G., Djurle, A., and Yuen, J. 2007. Identification and mapping of Lr3a and a linked leaf rust resistance gene in durum wheat. Crop Sci. 47: 1459-1466.

Herrera-Foessel, S. A., Singh, R. P., Huerta-Espino, J., Yuen, J., and Djurle, A. 2005. New genes for leaf rust resistance in CIMMYT durum wheats. Plant Dis. 89:809-814.

Huerta-Espino, J., and Roelfs, A. P. 1992. Leaf rust on durum wheats. Vortr. Pflanzenzuchtg. 24:100-102. 
Huerta-Espino, J., Singh, R., Herrera-Foessel, S., Perez-Lopez, J., and Figueroa-Lopez, P. 2009. First detection of virulence in Puccinia triticina to resistance genes $L r 27+L r 31$ present in durum wheat in Mexico. Plant Dis. 93:110.

Huerta-Espino, J., Singh, R. P., Germán, S., McCallum, B. D., Park, R. F., Chen, W. Q., Bhardwaj, S. C., and Goyeau, H. 2011. Global status of wheat leaf rust caused by Puccinia triticina. Euphytica 179:143-160.

Jin, Y., Singh, R. P., Ward, R. W., Wanyera, R., Kinyua, M. G., Njau, P., Fetch, T., Pretorius, Z. A., and Yahyaoui, A. 2007. Characterization of seedling infection types and adult plant infection responses of monogenic $\mathrm{Sr}$ gene lines to race TTKS of Puccinia graminis f. sp. tritici. Plant Dis. 91:10961099.

Jin, Y., Szabo, L. J., Pretorius, Z. A., Singh, R. P., Ward, R., and Fetch, T. 2008. Detection of virulence to resistance gene $S r 24$ within race TTKS of Puccinia graminis f. sp. tritici. Plant Dis. 92:923-926.

Kassa, M. T., You, F. M., Hiebert, C. W., Pozniak, C. J., Fobert, P. R., Sharpe, A. G., Menzies, J. G., Humphreys, D. G., Harrison, N. R., Fellers, J. P., and McCallum, B. D. 2017. Highly predictive SNP markers for efficient selection of the wheat leaf rust resistance gene Lr16. BMC Plant Biol. 17:45.

Kertho, A., Mamidi, S., Bonman, J. M., McClean, P. E., and Acevedo, M. 2015. Genome-wide association mapping for resistance to leaf and stripe rust in winter-habit hexaploid wheat landraces. PLoS One 10:e0129580.

Klindworth, D. L., Miller, J. D., Jin, Y., and Xu, S. S. 2007. Chromosomal location of genes for stem rust resistance in monogenic lines derived from tetraploid wheat accession ST464. Crop Sci. 47:1441-1450.

Klindworth, D. L., Miller, J. D., and Xu, S. S. 2006. Registration of rusty durum wheat. Crop Sci. 46:1012-1014.

Knott, D. R. 2000. Inheritance of resistance to stem rust in Medea durum wheat and the role of suppressors. Crop Sci. 40:98-102.

Kolmer, J. 2013. Leaf rust of wheat: Pathogen biology, variation and host resistance. Forests 4:70-84.

Kolmer, J. A. 2015. First report of a wheat leaf rust (Puccinia triticina) phenotype with high virulence to durum wheat in the Great Plains region of the United States. Plant Dis. 99:156.

Kosambi, D. D. 1943. The estimation of map distance from recombination values. Ann. Eugen. 12:172-175.

Letta, T., Olivera, P., Maccaferri, M., Jin, Y., Ammar, K., Badebo, A., Salvi, S., Noli, E., Crossa, J., and Tuberosa, R. 2014. Association mapping reveals novel stem rust resistance loci in durum wheat at the seedling stage. Plant Genome 7.

Liu, S., Zhang, X., Pumphrey, M. O., Stack, R. W., Gill, B. S., and Anderson, J. A. 2006. Complex microlinearity among wheat, rice, and barley revealed by fine mapping of the genomic region harboring a major QTL for resistance to fusarium head blight in wheat. Funct. Integr. Genomics 6:83-89.

Long, D. L., and Kolmer, J. A. 1989. A North American system of nomenclature for Puccinia recondita f. sp. tritici. Phytopathology 79:525-529.

Lorieux, M. 2012. MapDisto: Fast and efficient computation of genetic linkage maps. Mol. Breed. 30:1231-1235.

Maccaferri, M., Ricci, A., Salvi, S., Milner, S. G., Noli, E., Martelli, P. L., Casadio, R., Akhunov, E., Scalabrin, S., Vendramin, V., Ammar, K., Blanco, A., Desiderio, F., Distelfeld, A., Dubcovsky, J., Fahima, T., Faris, J., Korol, A., Massi, A., Mastrangelo, A. M., Morgante, M., Pozniak, C., N'Diaye, A., Xu, S., and Tuberosa, R. 2015. A high-density, SNP-based consensus map of tetraploid wheat as a bridge to integrate durum and common wheat genomics and breeding. Plant Biotechnol. J. 13:648-663.

Marais, G. F., McCallum, B., and Marais, A. S. 2008. Wheat leaf rust resistance gene Lr59 derived from Aegilops peregrina. Plant Breed. 127: $340-345$

Marais, G. F., Pretorius, Z. A., Wellings, C. R., McCallum, B., and Marais, A. S. 2005. Leaf rust and stripe rust resistance genes transferred to common wheat from Triticum dicoccoides. Euphytica 143:115-123.

Martinez, F., Sillero, J. C., and Rubiales, D. 2005. Pathogenic specialization of Puccinia triticina in Andalusia from 1998 to 2000. J. Phytopathol. 153: 344-349.

McCartney, C. A., Somers, D. J., McCallum, B. D., Thomas, J., Humphreys, D. G., Menzies, J. G., and Brown, P. D. 2005. Microsatellite tagging of the leaf rust resistance gene Lrl6 on wheat chromosome 2BSc. Mol. Breed. 15: 329-337.

McIntosh, R. A., and Brown, G. N. 1997. Anticipatory breeding for resistance to rust diseases in wheat. Annu. Rev. Phytopathol. 35:311-326.

McIntosh, R. A., Dubcovsky, J., Rogers, W. J., Morris, C., Appels, R., and Xia, X. C. 2014. Catalogue of gene symbols for wheat: 2013-2014 supplement. Online publication. Committee for the National BioResource Project (NBRP)/ KOMUGI, Japan. https://shigen.nig.ac.jp/wheat/komugi/genes/macgene/ supplement2013.pdf

McIntosh, R. A., Dubcovsky, J., Rogers, W. J., Morris, C. F., Appels, R., and Xia, X. C. 2009. Catalogue of gene symbols for wheat: 2009 supplement. KOMUGI Integrated Wheat Science Database. Online publication. http:// www.shigen.nig.ac.jp/wheat/komugi/genes/symbolClassList.jsp
McIntosh, R. A., and Dyck, P. L. 1975. Cytogenetical studies in wheat. VII Gene Lr23 for reaction to Puccinia recondita in Gabo and related cultivars. Aust. J. Biol. Sci. 28:201-212.

McIntosh, R. A., Wellings, C. R., and Park, R. F., eds. 1995. Wheat Rusts: An Atlas of Resistance Genes. Springer Netherlands, Dordrecht, The Netherlands.

McIntosh, R. A., Yamazaki, Y., Dubcovsky, J., Rogers, J., Morris, C., Appels, R., and Xia, X. C. 2013. Catalogue of gene symbols for wheat. Online publication. Committee for the National BioResource Project (NBRP)/ KOMUGI, Japan. https://shigen.nig.ac.jp/wheat/komugi/genes/download. jsp

Michelmore, R. W., Paran, I., and Kesseli, R. V. 1991. Identification of markers linked to disease-resistance genes by bulked segregant analysis: A rapid method to detect markers in specific genomic regions by using segregating populations. Proc. Natl. Acad. Sci. USA 88:9828-9832.

NASS. 2015. North Dakota 2015 Wheat Varieties. Online publication. United States Department of Agriculture-National Agricultural Statistics Service. http://www.nd.gov/seed/news/whtvr15.pdf

NASS. 2016. National statistics: Wheat, durum. Online publication. United States Department of Agriculture-National Agricultural Statistics Service. https://www.nass.usda.gov/Charts_and_Maps/A_to_Z/in-wheat_durum.php

Nazari, K., Mafi, M., Yahyaoui, A., Singh, R. P., and Park, R. F. 2009. Detection of wheat stem rust (Puccinia graminis f. sp. tritici) race TTKSK (Ug99) in Iran. Plant Dis. 93:317.

Nelson, J. C., Singh, R. P., Autrique, J. E., and Sorrells, M. E. 1997. Mapping genes conferring and suppressing leaf rust resistance in wheat. Crop Sci. 37: 1928-1935.

Newton, A. C., Fitt, B. D. L., Atkins, S. D., Walters, D. R., and Daniell, T. J. 2010. Pathogenesis, parasitism and mutualism in the trophic space of microbe-plant interactions. Trends Microbiol. 18:365-373.

Niu, Z., Klindworth, D. L., Yu, G., Friesen, T. L., Chao, S., Jin, Y., Cai, X., Ohm, J. B., Rasmussen, J. B., and Xu, S. S. 2014. Development and characterization of wheat lines carrying stem rust resistance gene $\mathrm{Sr} 43$ derived from Thinopyrum ponticum. Theor. Appl. Genet. 127:969-980.

Olivera, P., Newcomb, M., Szabo, L. J., Rouse, M., Johnson, J., Gale, S., Luster, D. G., Hodson, D., Cox, J. A., Burgin, L., and Hort, M. 2015. Phenotypic and genotypic characterization of race TKTTF of Puccinia graminis f. sp. tritici that caused a wheat stem rust epidemic in southern Ethiopia in 2013-14. Phytopathology 105:917-928.

Olivera, P. D., Jin, Y., Rouse, M., Badebo, A., Fetch, T., Singh, R. P., and Yahyaoui, A. 2012. Races of Puccinia graminis f. sp. tritici with combined virulence to $\mathrm{Sr} 13$ and $\mathrm{Sr} 9 \mathrm{e}$ in a field stem rust screening nursery in Ethiopia. Plant Dis. 96:623-628.

Ordoñez, M. E., and Kolmer, J. A. 2007a. Virulence phenotypes of a worldwide collection of Puccinia triticina from durum wheat. Phytopathology 97:344-351.

Ordoñez, M. E., and Kolmer, J. A. 2007b. Simple sequence repeat diversity of a worldwide collection of Puccinia triticina from durum wheat. Phytopathology 97:574-583.

Park, R. F., Mohler, V., Nazari, K., and Singh, D. 2014. Characterization and mapping of gene $L r 73$ conferring seedling resistance to Puccinia triticina in common wheat. Theor. Appl. Genet. 127:2041-2049.

Pirseyedi, S. M., Somo, M., Poudel, R. S., Cai, X., McCallum, B., Saville, B., Fetch, T., Chao, S., and Marais, F. 2015. Characterization of recombinants of the Aegilops peregrina-derived Lr59 translocation of common wheat. Theor. Appl. Genet. 128:2403-2414.

Pretorius, Z. A., Bender, C. M., Visser, B., and Terefe, T. 2010. First report of a Puccinia graminis f. sp. tritici race virulent to the $S r 24$ and $\mathrm{Sr} 31$ wheat stem rust resistance genes in South Africa. Plant Dis. 94:784.

Pretorius, Z. A., Singh, R. P., Wagoire, W. W., and Payne, T. S. 2000. Detection of virulence to wheat stem rust resistance gene Sr31 in Puccinia graminis. f. sp. tritici in Uganda. Plant Dis. 84:203.

Rahmatov, M., Rouse, M. N., Nirmala, J., Danilova, T., Friebe, B., Steffenson, B. J., and Johansson, E. 2016. A new 2DS-2RL Robertsonian translocation transfers stem rust resistance gene Sr59 into wheat. Theor. Appl. Genet. 129:1383-1392.

Ramirez-Gonzalez, R. H., Segovia, V., Bird, N., Fenwick, P., Holdgate, S., Berry, S., Jack, P., Caccamo, M., and Uauy, C. 2014. RNA-Seq bulked segregant analysis enables the identification of high-resolution genetic markers for breeding in hexaploid wheat. Plant Biotechnol. J. 13:613-624.

Ramirez-Gonzalez, R. H., Uauy, C., and Caccamo, M. 2015. PolyMarker: A fast polyploid primer design pipeline. Bioinformatics 31:2038-2039.

Reif, J. C., Zhang, P., Dreisigacker, S., Warburton, M. L., van Ginkel, M., Hoisington, D., Bohn, M., and Melchinger, A. E. 2005. Trends in genetic diversity during the history of wheat domestication and breeding. Theor. Appl. Genet. 110:859-864.

Riede, C. R., and Anderson, J. A. 1996. Linkage of RFLP markers to and aluminum tolerance gene in wheat. Crop Sci. 36:905-909.

Rouse, M. N., Nava, I. C., Chao, S., Anderson, J. A., and Jin, Y. 2012. Identification of markers linked to the race Ug99 effective stem rust 
resistance gene $\mathrm{Sr} 28$ in wheat (Triticum aestivum L.). Theor. Appl. Genet. 125:877-885.

Rowell, J. B. 1984. Controlled infection by Puccinia graminis f. sp. tritici under artificial conditions. Pages 291-332 in: The Cereal Rusts, Origins, Specificity, Structure, and Physiology, Vol. 1. W. R. Bushnell and A. P. Roelfs, eds. Academic Press, Gainesville, FL.

RustTracker.org. 2016. Pathotype Tracker - Where is Ug99?. http://rusttracker. cimmyt.org/?page_id=22

Sacco, F., Suarez, E. Y., and Naranjo, T. 1998. Mapping of the leaf rust resistance gene $L r 3$ on chromosome 6B of Sinvalocho MA wheat. Genome 41:686-690.

Singh, B., Bansal, U. K., Forrest, K. L., Hayden, M. J., Hare, R. A., and Bariana, H. S. 2010. Inheritance and chromosome location of leaf rust resistance in durum wheat cultivar Wollaroi. Euphytica 175:351-355.

Singh, H., Dhaliwal, H. S., and Gill, K. S. 1992. Diversity for leaf rust resistance in Triticum durum germplasm. Cereal Rusts Powdery Mildews Bull. 20:62-67.

Singh, R. P. 1991. Pathogenicity variations of Puccinia recondita f. sp. tritici and P. graminis f. sp. tritici in wheat-growing areas of Mexico during 1988 and 1989. Plant Dis. 75:790-794.

Singh, R. P., Bechere, E., and Abdalla, O. 1993. Genetic analysis of resistance to leaf rust in nine durum wheats. Plant Dis. 77:460-463.

Singh, R. P., Hodson, D. P., Huerta-Espino, J., Jin, Y., Bhavani, S., Njau, P., Herrera-Foessel, S., Singh, P. K., Singh, S., and Govindan, V. 2011. The emergence of $\mathrm{Ug} 99$ races of the stem rust fungus is a threat to world wheat production. Annu. Rev. Phytopathol. 49:465-481.

Singh, R. P., Hodson, D. P., Jin, Y., Lagudah, E. S., Ayliffe, M. A., Bhavani, S., Rouse, M. N., Pretorius, Z. A., Szabo, L. J., Huerta-Espino, J., Basnet, B. R., Lan, C., and Hovmøller, M. S. 2015. Emergence and spread of new races of wheat stem rust fungus: Continued threat to food security and prospects of genetic control. Phytopathology 105:872-884.

Singh, R. P., Huerta-Espino, J., Fuentes, G., Duvellier, E., Gilchrist, L., Henry, M., and Nicol, J. M. 2005. Resistance to diseases. Pages 291-328 in: Durum
Wheat Breeding: Current Approaches and Future Strategies, Vol. 1. C. Royo, M. Miloudi, and N. di Fonzo, eds. Food Product Press, New York.

Singh, R. P., Huerta-Espino, J., Pfeiffer, W., and Figueroa-Lopez, P. 2004. Occurrence and impact of a new leaf rust race on durum wheat in Northwestern Mexico from 2001 to 2003. Plant Dis. 88:703-708.

Singh, R. P., and McIntosh, R. A. 1984. Complementary genes for reaction to Puccinia recondita tritici in Triticum aestivum. II. Cytogenetic studies. Can. J. Genet. Cytol. 26:736-742.

Soleiman, N. H., Solis, I., Soliman, M. H., Sillero, J. C., Villegas, D., Alvaro, F., Royo, C., Serra, J., Ammar, K., and Martínez-Moreno, F. 2016. Short communication: Emergence of a new race of leaf rust with combined virulence to Lr14a and Lr72 genes on durum wheat. Span. J. Agric. Res. 14: e10SC02.

Stakman, E. C., Stewart, D. M., and Loegering, W. Q. 1962. Identification of physiologic races of Puccinia graminis var. tritici. U.S. Dep. Agric. Agric. Res. Serv. E-617.

Vavilov, N. I. 1951. Pages 37-39 in: The Origin, Variation, Immunity, and Breeding of Cultivated Plants: Selected Writings. K. S. Chester, ed. The Ronald Press Company, New York.

Watson, I. A., and Luig, N. H. 1961. Leaf rust on wheat in Australia: A systematic scheme for the classification of strains. Proc. Linn. Soc. N. S. W. 86:241-250.

Yu, G. T., Zhang, Q. J., Friesen, T. L., Rouse, M. N., Jin, Y., Zhong, S., Rasmussen, J. B., Lagudah, E. S., and Xu, S. S. 2015. Identification and mapping of Sr46 from Aegilops tauschii accession CIae 25 conferring resistance to race TTKSK (Ug99) of wheat stem rust pathogen. Theor. Appl. Genet. 128:431-443.

Yu, L. X., Barbier, H., Rouse, M. N., Singh, S., Singh, R. P., Bhavani, S., Huerta-Espino, J., and Sorrells, M. E. 2014. A consensus map for Ug99 stem rust resistance loci in wheat. Theor. Appl. Genet. 127:1561-1581.

Zhang, H. T., and Knott, D. R. 1990. Inheritance of leaf rust resistance in durum wheat. Crop Sci. 30:1218-1222. 